\title{
Interpolation of Cesàro sequence and function spaces
}

\author{
by \\ Sergey V. Astashkin (Samara) and Lech Maligranda (Luleå)
}

\begin{abstract}
The interpolation properties of Cesàro sequence and function spaces are investigated. It is shown that $\operatorname{Ces}_{p}(I)$ is an interpolation space between $\operatorname{Ces}_{p_{0}}(I)$ and $\operatorname{Ces}_{p_{1}}(I)$ for $1<p_{0}<p_{1} \leq \infty$ and $1 / p=(1-\theta) / p_{0}+\theta / p_{1}$ with $0<\theta<1$, where $I=[0, \infty)$ or $[0,1]$. The same result is true for Cesàro sequence spaces. On the other hand, $\operatorname{Ces}_{p}[0,1]$ is not an interpolation space between $\operatorname{Ces}_{1}[0,1]$ and $\operatorname{Ces}_{\infty}[0,1]$.
\end{abstract}

1. Introduction and preliminaries. The structure of Cesàro sequence and function spaces was investigated by several authors (see, for example, Be, MPS, A, AM and references therein). Here we are interested in interpolation properties of these spaces. The main purpose is to give interpolation theorems for the Cesàro sequence spaces $\operatorname{ces}_{p}$ and Cesàro function spaces $\operatorname{Ces}_{p}(I)$ on $I=[0, \infty)$ and $I=[0,1]$. In the case of $I=[0, \infty)$ some interpolation results for Cesàro function spaces are contained implicitly in [MS]. Moreover, using the so-called $K^{+}$-method of interpolation it was proved in CFM that the Cesàro sequence space $\operatorname{ces}_{p}$ is an interpolation space with respect to the couple $\left(l_{1}, l_{1}\left(2^{-k}\right)\right)$.

Our main aim is to give a rather complete description of Cesàro spaces as interpolation spaces with respect to appropriate couples of weighted $L_{1^{-}}$ spaces as well as Cesàro spaces. For example, if either $I=[0, \infty)$ or $[0,1]$ and $1<p_{0}<p_{1} \leq \infty$ with $1 / p=(1-\theta) / p_{0}+\theta / p_{1}$ for $0<\theta<1$, then

$$
\left(\operatorname{Ces}_{p_{0}}(I), \operatorname{Ces}_{p_{1}}(I)\right)_{\theta, p}=\operatorname{Ces}_{p}(I) \text { and }\left(\operatorname{ces}_{p_{0}}, \operatorname{ces}_{p_{1}}\right)_{\theta, p}=\operatorname{ces}_{p},
$$

where $(\cdot, \cdot)_{\theta, p}$ denotes the $K$-method of interpolation.

We have a completely different situation in a more interesting and nontrivial case when $I=[0,1]$ and $p_{0}=1, p_{1}=\infty$. It turns out that $\operatorname{Ces}_{p}[0,1]$ is not an interpolation space between $\operatorname{Ces}_{1}[0,1]$ and $\operatorname{Ces}_{\infty}[0,1]$, whereas $\left(\operatorname{Ces}_{1}[0,1], \operatorname{Ces}_{\infty}[0,1]\right)_{\theta, p}$ for $1<p<\infty$ is a weighted Cesàro function space.

2010 Mathematics Subject Classification: Primary 46E30, 46B70; Secondary 46B20.

Key words and phrases: Cesàro sequence and function spaces, weighted Cesàro function spaces, Copson sequence and function spaces, interpolation, $K$-functional, $K$-method of interpolation. 
Let us collect some necessary definitions and notations related to the interpolation theory of operators as well as Cesàro, Copson and down spaces.

For two normed spaces $X$ and $Y$ the symbol $X \stackrel{C}{\hookrightarrow} Y$ means that the imbedding $X \subset Y$ is continuous with norm not greater than $C$, i.e., $\|x\|_{Y} \leq$ $C\|x\|_{X}$ for all $x \in X$, and $X \hookrightarrow Y$ means that $X \stackrel{C}{\hookrightarrow} Y$ for some $C>0$. Moreover, $X=Y$ means that $X \hookrightarrow Y$ and $Y \hookrightarrow X$, that is, the spaces are the same and the norms are equivalent. If $f$ and $g$ are real functions, then $f \approx g$ means that $c^{-1} g \leq f \leq c g$ for some $c \geq 1$.

For a Banach couple $\bar{X}=\left(X_{0}, X_{1}\right)$ of two compatible Banach spaces $X_{0}$ and $X_{1}$ consider the Banach spaces $X_{0} \cap X_{1}$ and $X_{0}+X_{1}$ with their natural norms

$$
\|f\|_{X_{0} \cap X_{1}}=\max \left(\|f\|_{X_{0}},\|f\|_{X_{1}}\right) \quad \text { for } f \in X_{0} \cap X_{1},
$$

and for $f \in X_{0}+X_{1}$,

$$
\|f\|_{X_{0}+X_{1}}=\inf \left\{\left\|f_{0}\right\|_{X_{0}},+\left\|f_{1}\right\|_{X_{1}}: f=f_{0}+f_{1}, f_{0} \in X_{0}, f_{1} \in X_{1}\right\} .
$$

For more careful definitions of a Banach couple, intermediate and interpolation spaces with some results introduced briefly below, see [BK, pp. 91-173, 289-314, 338-359] and [BS, pp. 95-116].

A Banach space $X$ is called an intermediate space between $X_{0}$ and $X_{1}$ if $X_{0} \cap X_{1} \hookrightarrow X \hookrightarrow X_{0}+X_{1}$. Such a space $X$ is called an interpolation space between $X_{0}$ and $X_{1}$ (and we write $X \in \operatorname{Int}\left(X_{0}, X_{1}\right)$ ) if, for any bounded linear operator $T: X_{0}+X_{1} \rightarrow X_{0}+X_{1}$ whose restriction $T_{\mid X_{i}}: X_{i} \rightarrow X_{i}$ is bounded for $i=0,1$, the restriction $T_{\mid X}: X \rightarrow X$ is also bounded and $\|T\|_{X \rightarrow X} \leq C \max \left\{\|T\|_{X_{0} \rightarrow X_{0}},\|T\|_{X_{1} \rightarrow X_{1}}\right\}$ for some $C \geq 1$. If $C=1$, then $X$ is called an exact interpolation space between $X_{0}$ and $X_{1}$.

An interpolation method or interpolation functor $\mathcal{F}$ is a construction (a rule) which assigns to every Banach couple $\bar{X}=\left(X_{0}, X_{1}\right)$ an interpolation space $\mathcal{F}(\bar{X})$ between $X_{0}$ and $X_{1}$. The interpolation functor $\mathcal{F}$ is called exact if the space $\mathcal{F}(\bar{X})$ is an exact interpolation space for every Banach couple $\bar{X}$. One of the most important interpolation methods is the $K$-method, also known as the real Lions-Peetre interpolation method. For a Banach couple $\bar{X}=\left(X_{0}, X_{1}\right)$ the Peetre $K$-functional of an element $f \in X_{0}+X_{1}$ is defined for $t>0$ by

$$
K\left(t, f ; X_{0}, X_{1}\right)=\inf \left\{\left\|f_{0}\right\|_{X_{0}}+t\left\|f_{1}\right\|_{X_{1}}: f=f_{0}+f_{1}, f_{0} \in X_{0}, f_{1} \in X_{1}\right\} .
$$

Then the spaces of the $K$-method of interpolation are

$$
\begin{aligned}
\left(X_{0}, X_{1}\right)_{\theta, p}=\left\{f \in X_{0}+X_{1}\right. & \\
\|f\|_{\theta, p} & \left.=\left(\int_{0}^{\infty}\left[t^{-\theta} K\left(t, f ; X_{0}, X_{1}\right)\right]^{p} \frac{d t}{t}\right)^{1 / p}<\infty\right\}
\end{aligned}
$$


if $0<\theta<1$ and $1 \leq p<\infty$, and

$$
\left(X_{0}, X_{1}\right)_{\theta, \infty}=\left\{f \in X_{0}+X_{1}:\|f\|_{\theta, \infty}=\sup _{t>0} K\left(t, f ; X_{0}, X_{1}\right) / t^{\theta}<\infty\right\}
$$

if $0 \leq \theta \leq 1$. Very useful in calculations is the so-called reiteration formula showing the stability of the $K$-method of interpolation. If $1 \leq p_{0}, p_{1}, p \leq \infty$, $0<\theta_{0}, \theta_{1}, \theta<1$ and $\theta_{0} \neq \theta_{1}$, then with equivalent norms

$$
\left(\left(X_{0}, X_{1}\right)_{\theta_{0}, p_{0}},\left(X_{0}, X_{1}\right)_{\theta_{1}, p_{1}}\right)_{\theta, p}=\left(X_{0}, X_{1}\right)_{\eta, p},
$$

where $\eta=(1-\theta) \theta_{0}+\theta \theta_{1}$ (see [BS, Theorem 2.4, p. 311], [BL, Theorems 3.5.3], [BK, Theorem 3.8.10]) and [Tr, Theorem 1.10.2]).

The space $\left(X_{0}, X_{1}\right)_{\Phi}^{K}$ of the general $K$-method of interpolation, where $\Phi$ is a parameter of the $K$-method, i.e., a Banach function space on $((0, \infty), d t / t)$ containing the function $t \mapsto \min \{1, t\}$, is the Banach space of all $f \in X_{0}+X_{1}$ such that $K\left(\cdot, f ; X_{0}, X_{1}\right) \in \Phi$ with the norm $\|f\|_{K_{\Phi}}=\left\|K\left(\cdot, f ; X_{0}, X_{1}\right)\right\|_{\Phi}$. The space $\left(X_{0}, X_{1}\right)_{\Phi}^{K}$ is an exact interpolation space between $X_{0}$ and $X_{1}$.

In particular, if $L_{p}=L_{p}(\Omega, \mu)$, where $(\Omega, \mu)$ is a complete $\sigma$-finite measure space, then for any $f \in L_{1}+L_{\infty}$ we have

$$
K\left(t, f ; L_{1}, L_{\infty}\right)=\int_{0}^{t} f^{*}(s) d s .
$$

Here and below, $f^{*}$ denotes the non-increasing rearrangement of $|f|$ defined by $f^{*}(s)=\inf \{\lambda>0: \mu(\{x \in \Omega:|f(x)|>\lambda\}) \leq s\}$ (see [BK, Proposition 3.1.1], [KPS, pp. 78-79], [BS, Theorem 6.2, pp. 74-75]). Moreover, for two non-negative weight functions $w_{0}, w_{1}$ and for $f \in L_{1}\left(w_{0}\right)+L_{1}\left(w_{1}\right)$ we have

$$
K\left(t, f ; L_{1}\left(w_{0}\right), L_{1}\left(w_{1}\right)\right)=\left\|\min \left(w_{0}, t w_{1}\right) f\right\|_{L_{1}}
$$

(see [BK, Proposition 3.1.17] and [Ov, p. 391]).

If the inequality $K\left(t, g ; X_{0}, X_{1}\right) \leq K\left(t, f ; X_{0}, X_{1}\right)(t>0)$ with $f \in X$ and $g \in X_{0}+X_{1}$ implies that $g \in X$ and $\|g\|_{X} \leq C\|f\|_{X}$ for any $X \in$ $\operatorname{Int}\left(X_{0}, X_{1}\right)$ and some $C \geq 1$ independent of $X, f$ and $g$, then $\left(X_{0}, X_{1}\right)$ is called a $K$-monotone or Calderón-Mityagin couple. For every $K$-monotone couple $\left(X_{0}, X_{1}\right)$ the spaces $\left(X_{0}, X_{1}\right)_{\Phi}^{K}$ of the general $K$-method are the only interpolation spaces between $X_{0}$ and $X_{1}$ (see [BK]).

Now, we recall the definitions of Cesàro spaces. The Cesàro sequence spaces $\operatorname{ces}_{p}$ are the sets of real sequences $x=\left\{x_{k}\right\}$ such that

$$
\|x\|_{\operatorname{ces}(p)}=\left[\sum_{n=1}^{\infty}\left(\frac{1}{n} \sum_{k=1}^{n}\left|x_{k}\right|\right)^{p}\right]^{1 / p}<\infty \quad \text { for } 1 \leq p<\infty,
$$

and

$$
\|x\|_{\operatorname{ces}(\infty)}=\sup _{n \in \mathbb{N}} \frac{1}{n} \sum_{k=1}^{n}\left|x_{k}\right|<\infty \quad \text { for } p=\infty .
$$


The Cesàro function spaces $\operatorname{Ces}_{p}=\operatorname{Ces}_{p}(I)$ are the classes of Lebesgue measurable real functions $f$ on $I=[0,1]$ or $I=[0, \infty)$ such that

$$
\|f\|_{\operatorname{Ces}(p)}=\left[\int_{I}\left(\frac{1}{x} \int_{0}^{x}|f(t)| d t\right)^{p} d x\right]^{1 / p}<\infty \quad \text { for } 1 \leq p<\infty
$$

and

$$
\|f\|_{\operatorname{Ces}(\infty)}=\sup _{0<x \in I} \frac{1}{x} \int_{0}^{x}|f(t)| d t<\infty \quad \text { for } p=\infty .
$$

Cesàro spaces are Banach lattices which are not symmetric except when they are trivial, namely, $\operatorname{ces}_{1}=\{0\}, \operatorname{Ces}_{1}[0, \infty)=\{0\}$. By a symmetric space we mean a Banach lattice $X$ on $I$ with the additional property: if $g^{*}(t)=f^{*}(t)$ for all $t>0, f \in X$ and $g \in L^{0}(I)$ (the set of all classes of Lebesgue measurable real functions on $I$ ), then $g \in X$ and $\|g\|_{X}=\|f\|_{X}$ (cf. [BS], [KPS]). Moreover, $l_{p} \stackrel{p^{\prime}}{\hookrightarrow} \operatorname{ces}_{p}, L_{p}(I) \stackrel{p^{\prime}}{\hookrightarrow} \operatorname{Ces}_{p}(I)$ for $1<p \leq \infty$ (in what follows $1 / p+1 / p^{\prime}=1$ ), and if $1<p<q<\infty$, then $\operatorname{ces}_{p} \stackrel{1}{\hookrightarrow} \operatorname{ces}_{q} \stackrel{1}{\hookrightarrow} \operatorname{ces}_{\infty}$. Also for $I=[0,1]$ and $1<p<q<\infty$ we have $L_{\infty} \stackrel{1}{\hookrightarrow} \operatorname{Ces}_{\infty} \stackrel{1}{\hookrightarrow} \operatorname{Ces}_{q} \stackrel{1}{\hookrightarrow}$

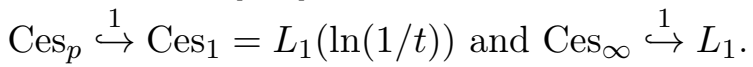

Let $1 \leq p<\infty$. The Copson sequence spaces $\operatorname{cop}_{p}$ are the sets of real sequences $x=\left\{x_{k}\right\}$ such that

$$
\|x\|_{\operatorname{cop}(p)}=\left[\sum_{n=1}^{\infty}\left(\sum_{k=n}^{\infty} \frac{\left|x_{k}\right|}{k}\right)^{p}\right]^{1 / p}<\infty,
$$

and the Copson function spaces $\operatorname{Cop}_{p}=\operatorname{Cop}_{p}(I)$ are the classes of Lebesgue measurable real functions $f$ on $I=[0, \infty)$ or $I=[0,1]$ such that

$$
\|f\|_{\operatorname{Cop}(p)}=\left[\int_{0}^{\infty}\left(\int_{x}^{\infty} \frac{|f(t)|}{t} d t\right)^{p} d x\right]^{1 / p}<\infty \quad \text { for } I=[0, \infty),
$$

and

$$
\|f\|_{\operatorname{Cop}(p)}=\left[\int_{0}^{1}\left(\int_{x}^{1} \frac{|f(t)|}{t} d t\right)^{p} d x\right]^{1 / p}<\infty \quad \text { for } I=[0,1] .
$$

Sometimes we will use the Cesàro operators

$$
C_{d} x(n)=\frac{1}{n} \sum_{k=1}^{n}\left|x_{k}\right|, \quad C f(x)=\frac{1}{x} \int_{0}^{x}|f(t)| d t
$$

and the Copson operators

$$
C_{d}^{*} x(n)=\sum_{k=n}^{\infty} \frac{\left|x_{k}\right|}{k}, \quad C^{*} f(x)=\int_{(x, \infty) \cap I} \frac{|f(t)|}{t} d t
$$


related to appropriate spaces. Then $\operatorname{ces}_{p}\left(\operatorname{resp} . \operatorname{cop}_{p}\right)$ consists of all real sequences $x=\left\{x_{k}\right\}$ such that $C_{d} x \in l_{p}$ (resp. $C_{d}^{*} x \in l_{p}$ ), and $\operatorname{Ces}_{p}(I)$ (resp. $\left.\operatorname{Cop}_{p}(I)\right)$ consists of all classes of Lebesgue measurable real functions $f$ on $I$ such that $C f \in L_{p}(I)$ (resp. $C^{*} f \in L_{p}(I)$ ) with natural norms. By the Copson inequalities (cf. [HLP, Theorems 328 and 331], [Be, p. 25] and [KMP, p. 159]), valid for $1 \leq p<\infty$, we have $\left\|C_{d}^{*} x\right\|_{l_{p}} \leq p\|x\|_{l_{p}}$ for $x \in l_{p}$ and $\left\|C^{*} f\right\|_{L_{p}(I)} \leq p\|f\|_{L_{p}(I)}$ for $f \in L_{p}(I)$. Therefore, $l_{p} \stackrel{p}{\hookrightarrow} \operatorname{cop}_{p}$ and $L_{p} \stackrel{p}{\hookrightarrow} \mathrm{Cop}_{p}$.

We can define similarly the spaces $\operatorname{cop}_{\infty}$ and $\operatorname{Cop}_{\infty}$ but it is easy to see that $\operatorname{cop}_{\infty}=l_{1}(1 / k)$ and $\operatorname{Cop}_{\infty}=L_{1}(1 / t)$. Moreover, for $I=[0,1]$ we have $L_{p} \stackrel{p}{\hookrightarrow} \operatorname{Cop}_{p} \stackrel{1}{\hookrightarrow} \mathrm{Cop}_{1}=L_{1}$.

We will also consider more general Cesàro spaces $\operatorname{Ces}_{E}(I)$, where $E$ is a Banach function space on $I$ with the natural norm $\|f\|_{\operatorname{Ces}(E)}=\|C f\|_{E}$.

For a Banach function space $E$ on $I=[0, \infty)$ the down space $E^{\downarrow}$ is the collection of all $f \in L^{0}$ such that

$$
\|f\|_{E \downarrow}=\sup \int_{I}|f(t)| g(t) d t<\infty,
$$

where the supremum is taken over all non-negative, non-increasing Lebesgue measurable functions $g$ from the Köthe dual $E^{\prime}$ of $E$ such that $\|g\|_{E^{\prime}} \leq 1$. Let us recall that the Köthe dual of a Banach function space $E$ is defined as

$$
E^{\prime}=\left\{f \in L^{0}:\|f\|_{E^{\prime}}=\sup _{\|g\|_{E} \leq 1} \int_{I}|f(t) g(t)| d t<\infty\right\} .
$$

It is routine to check that the space $E^{\downarrow}$ has the Fatou property, that is, if $0 \leq f_{n}$ increases to $f$ a.e. on $I$ and $\sup _{n \in \mathbb{N}}\left\|f_{n}\right\|_{E^{\downarrow}}<\infty$, then $f \in E^{\downarrow}$ and $\left\|f_{n}\right\|_{E^{\downarrow}}$ increases to $\|f\|_{E^{\downarrow}}$. Moreover, $E^{\prime \prime} \stackrel{1}{\hookrightarrow} E^{\downarrow}$, where $E^{\prime \prime}$ is the second Köthe dual of $E$. Recall also that a Banach function space $E$ has the Fatou property if and only if $E=E^{\prime \prime}$ with equality of norms.

Sinnamon [Si01, Theorem 3.1] proved that if $E$ is a symmetric space on $I=[0, \infty)$, then $\|f\|_{E \downarrow} \approx\|C f\|_{E}$ if and only if the Cesàro operator $C: E \rightarrow E$ is bounded. In particular, then $E^{\downarrow}=\operatorname{Ces}_{E}$. Moreover, $\left(L_{1}\right)^{\downarrow}=L_{1}$ since

$$
\|f\|_{L_{1}^{\downarrow}}=\sup _{0 \leq g} \frac{\int_{0}^{\infty}|f(t)| g(t) d t}{\|g\|_{L_{\infty}}} \geq \sup _{0 \leq g \downarrow} \frac{\int_{0}^{\infty}|f(t)| g(t) d t}{\|g\|_{L_{\infty}}} \geq \frac{\int_{0}^{\infty}|f(t)| d t}{\|1\|_{L_{\infty}}}=\|f\|_{L_{1}}
$$

(cf. [MS, p. 194]).

The paper is organized as follows. In Section 2 we prove that the Cesàro and Copson sequence and function spaces on $[0, \infty)$ are interpolation spaces obtained by the $K$-method from weighted $L_{1}$-spaces. At the same time, in the case of $I=[0,1]$, only the Copson spaces can be described as interpola- 
tion spaces with respect to the analogous couple of weighted $L_{1}$-spaces (see Theorem 1(iii)). In particular, we obtain a new description of the interpolation spaces $\left(L_{1}, L_{1}(1 / t)\right)_{1-1 / p, p}$ in the off-diagonal case both for $I=[0, \infty)$ and $I=[0,1]$.

In Section 3 it is shown that the Cesàro function spaces $\operatorname{Ces}_{p}[0, \infty)$, $1<p<\infty$, can be obtained by the $K$-method of interpolation also from the couple $\left(L_{1}[0, \infty), \operatorname{Ces}_{\infty}[0, \infty)\right)$. Hence, applying the reiteration theorem, we conclude that $\operatorname{Ces}_{p}[0, \infty)$ is an interpolation space with respect to the couple $\left(\operatorname{Ces}_{p_{0}}[0, \infty), \operatorname{Ces}_{p_{1}}[0, \infty)\right)$ for arbitrary $1<p_{0}<p_{1} \leq \infty$ and $1 / p=$ $(1-\theta) / p_{0}+\theta / p_{1}$ with $0<\theta<1$.

In Section 4 interpolation of Cesàro function spaces on $[0,1]$ is investigated. We prove that for $1<p<\infty$,

$$
\left(L_{1}(1-t)[0,1], \operatorname{Ces}_{\infty}[0,1]\right)_{\theta, p}=\operatorname{Ces}_{p}[0,1] \quad \text { with } \theta=1-1 / p .
$$

As a consequence of this result and the reiteration equality 1.2 , we infer

$$
\left(\operatorname{Ces}_{p_{0}}[0,1], \operatorname{Ces}_{p_{1}}[0,1]\right)_{\theta, p}=\operatorname{Ces}_{p}[0,1]
$$

for all $1<p_{0}<p_{1} \leq \infty$ and $1 / p=(1-\theta) / p_{0}+\theta / p_{1}$ with $0<\theta<1$.

We are also interested in description of interpolation spaces between $\operatorname{Ces}_{1}[0,1]$ and $\operatorname{Ces}_{\infty}[0,1]$. In Section 5 , in Theorem 3, we find an equivalent expression for the $K$-functional with respect to this couple and then in Section 6 we prove that the real interpolation spaces

$$
\left(\operatorname{Ces}_{1}[0,1], \operatorname{Ces}_{\infty}[0,1]\right)_{1-1 / p, p}
$$

for $1<p<\infty$ can be identified with the weighted Cesàro function spaces $\operatorname{Ces}_{p}(\ln (e / t))[0,1]$.

Finally, in Section 7, we show in Theorem 6 that $\operatorname{Ces}_{p}[0,1]$ for $1<p<\infty$ are not interpolation spaces between $\operatorname{Ces}_{1}[0,1]$ and $\operatorname{Ces}_{\infty}[0,1]$.

2. Cesàro and Copson spaces as interpolation spaces with respect to weighted $L_{1}$-spaces. We start with the main result in this part.

THEOREM 2.1.

(i) If $1<p<\infty$, then

$$
\left(l_{1}, l_{1}(1 / k)\right)_{1-1 / p, p}=\operatorname{ces}_{p}=\operatorname{cop}_{p} .
$$

(ii) If $I=[0, \infty)$ and $1<p<\infty$, then

$$
\left(L_{1}, L_{1}(1 / t)\right)_{1-1 / p, p}=\operatorname{Ces}_{p}=\operatorname{Cop}_{p} .
$$

(iii) If $I=[0,1]$ and $1<p \leq \infty$, then

$$
\left(L_{1}, L_{1}(1 / t)\right)_{1-1 / p, p}=\operatorname{Cop}_{p} \text {. }
$$

Moreover, $\operatorname{Cop}_{p} \stackrel{p^{\prime}}{\rightarrow} \operatorname{Ces}_{p}$ and the reverse imbedding does not hold. 
Proof. (i) If $f \in l_{1}+l_{1}(1 / k)$, then $K\left(t, x ; l_{1}, l_{1}(1 / k)\right)=t \sum_{k=1}^{\infty}\left|x_{k}\right| / k$ for $0<t \leq 1$, and

$$
K\left(t, x ; l_{1}, l_{1}(1 / k)\right)=\sum_{k=1}^{\infty}\left|x_{k}\right| \min (1, t / k)=\sum_{k=1}^{[t]}\left|x_{k}\right|+t \sum_{k=[t]+1}^{\infty} \frac{\left|x_{k}\right|}{k} .
$$

for $t \geq 1$. Therefore, for $n \leq t<n+1(n \geq 1)$, we have

$$
\frac{K\left(t, x ; l_{1}, l_{1}(1 / k)\right)}{t} \leq \frac{1}{n} \sum_{k=1}^{n}\left|x_{k}\right|+\sum_{k=n+1}^{\infty} \frac{\left|x_{k}\right|}{k}=C_{d} x(n)+C_{d}^{*} x(n+1) .
$$

Since

$$
\begin{aligned}
C_{d} C_{d}^{*} x(n) & =\frac{1}{n} \sum_{m=1}^{n}\left(\sum_{k=m}^{\infty} \frac{\left|x_{k}\right|}{k}\right) \\
& =\frac{1}{n}\left[\sum_{k=1}^{n}\left(\sum_{m=1}^{k} \frac{\left|x_{k}\right|}{k}\right)+\sum_{k=n+1}^{\infty}\left(\sum_{m=1}^{n} \frac{\left|x_{k}\right|}{k}\right)\right] \\
& =\frac{1}{n} \sum_{k=1}^{n}\left|x_{k}\right|+\sum_{k=n+1}^{\infty} \frac{\left|x_{k}\right|}{k}=C_{d} x(n)+C_{d}^{*} x(n+1),
\end{aligned}
$$

it follows that, for $n \leq t<n+1(n \geq 1)$,

$$
\frac{K\left(t, x ; l_{1}, l_{1}(1 / k)\right)}{t} \leq C_{d} C_{d}^{*} x(n) .
$$

Using the classical Hardy inequality (cf. [HLP, Theorem 326] or [KMP, Theorem 1]), we obtain

$$
\begin{aligned}
\|x\|_{1-1 / p, p} & =\left(\int_{0}^{\infty}\left(\frac{K\left(t, x ; l_{1}, l_{1}(1 / k)\right)}{t}\right)^{p} d t\right)^{1 / p} \\
& =\left[C_{d}^{*} x(1)^{p}+\sum_{n=1}^{\infty} \int_{n}^{n+1}\left(\frac{K(t, x)}{t}\right)^{p} d t\right]^{1 / p} \\
& \leq\left[C_{d}^{*} x(1)^{p}+\sum_{n=1}^{\infty}\left(C_{d} C_{d}^{*} x(n)\right)^{p}\right]^{1 / p} \\
& \leq C_{d}^{*} x(1)+\left\|C_{d} C_{d}^{*} x\right\|_{l_{p}} \leq C_{d}^{*} x(1)+p^{\prime}\left\|C_{d}^{*} x\right\|_{l_{p}} \\
& \leq\left(p^{\prime}+1\right)\left\|C_{d}^{*} x\right\|_{l_{p}}=\left(p^{\prime}+1\right)\|x\|_{\operatorname{cop}(p)} .
\end{aligned}
$$

This means that $\operatorname{cop}_{p} \hookrightarrow\left(l_{1}, l_{1}(1 / k)\right)_{1-1 / p, p}$. On the other hand, for $n \leq t<$ $n+1(n \geq 1)$, we have

$$
\frac{K\left(t, x ; l_{1}, l_{1}(1 / k)\right)}{t} \geq \sum_{k=n+1}^{\infty} \frac{\left|x_{k}\right|}{k}=C_{d}^{*} x(n+1)
$$


and

$$
\begin{aligned}
\|x\|_{1-1 / p, p} & =\left(\int_{0}^{\infty}\left(\frac{K\left(t, x ; l_{1}, l_{1}(1 / k)\right)}{t}\right)^{p} d t\right)^{1 / p} \\
& \geq\left(C_{d}^{*} x(1)^{p}+\sum_{n=1}^{\infty} C_{d}^{*} x(n+1)^{p}\right)^{1 / p}=\left\|C_{d}^{*} x\right\|_{l_{p}}=\|x\|_{\operatorname{cop}(p)},
\end{aligned}
$$

which gives the reverse imbedding $\left(l_{1}, l_{1}(1 / k)\right)_{1-1 / p, p} \stackrel{1}{\hookrightarrow} \operatorname{cop}_{p}$. The equality $\operatorname{ces}_{p}=\operatorname{cop}_{p}, 1<p<\infty$, was proved by Bennett (cf. [Be, Theorems 4.5 and $6.6])$.

(ii) For $f \in L_{1}+L_{1}(1 / s)=L_{1}(\min (1,1 / s))$ we have

$$
\begin{aligned}
K\left(t, f ; L_{1}, L_{1}(1 / s)\right) & =\int_{0}^{\infty}|f(s)| \min (1, t / s) d s \\
& =\int_{0}^{t}|f(s)| d s+t \int_{t}^{\infty} \frac{|f(s)|}{s} d s .
\end{aligned}
$$

Thus,

$$
\frac{K\left(t, f ; L_{1}, L_{1}(1 / s)\right)}{t}=C f(t)+C^{*} f(t), \quad t>0,
$$

and therefore

$$
\|f\|_{1-1 / p, p}=\left(\int_{0}^{\infty}\left(\frac{K\left(t, f ; L_{1}, L_{1}(1 / s)\right)}{t}\right)^{p} d t\right)^{1 / p}=\left\|C f+C^{*} f\right\|_{L_{p}(0, \infty)} .
$$

Since, by the Fubini theorem,

$$
\begin{aligned}
C^{*} C f(t) & =\int_{t}^{\infty}\left(\frac{1}{u^{2}} \int_{0}^{u}|f(s)| d s\right) d u \\
& =\int_{0}^{t}\left(\int_{t}^{\infty} \frac{1}{u^{2}} d u\right)|f(s)| d s+\int_{t}^{\infty}\left(\int_{s}^{\infty} \frac{1}{u^{2}} d u\right)|f(s)| d s \\
& =\frac{1}{t} \int_{0}^{t}|f(s)| d s+\int_{t}^{\infty} \frac{|f(s)|}{s} d s=C f(t)+C^{*} f(t),
\end{aligned}
$$

from the Copson inequality (cf. [HLP, Theorem 328]) it follows that

$$
\begin{aligned}
\|f\|_{\operatorname{Ces}(p)} & =\|C f\|_{L_{p}(0, \infty)} \leq\left\|C f+C^{*} f\right\|_{L_{p}(0, \infty)} \\
& =\left\|C^{*} C f\right\|_{L_{p}(0, \infty)} \leq p\|C f\|_{L_{p}(0, \infty)}=p\|f\|_{\operatorname{Ces}(p)} .
\end{aligned}
$$

Combining this with (2.1), we obtain $\|f\|_{1-1 / p, p} \approx\|f\|_{\operatorname{Ces}(p)}$. 
On the other hand, since

$$
\begin{aligned}
C C^{*} f(t) & =\frac{1}{t} \int_{0}^{t}\left(\int_{u}^{\infty} \frac{|f(s)|}{s} d s\right) d u \\
& =\frac{1}{t} \int_{0}^{t}\left(\int_{0}^{s} d u\right) \frac{|f(s)|}{s} d s+\frac{1}{t} \int_{t}^{\infty}\left(\int_{0}^{t} d u\right) \frac{|f(s)|}{s} d s \\
& =\frac{1}{t} \int_{0}^{t}|f(s)| d s+\int_{t}^{\infty} \frac{|f(s)|}{s} d s=C f(t)+C^{*} f(t),
\end{aligned}
$$

by the Hardy inequality,

$$
\begin{aligned}
\|f\|_{\operatorname{Cop}(p)} & =\left\|C^{*} f\right\|_{L_{p}(0, \infty)} \leq\left\|C f+C^{*} f\right\|_{L_{p}(0, \infty)} \\
& =\left\|C C^{*} f\right\|_{L_{p}(0, \infty)} \leq p^{\prime}\left\|C^{*} f\right\|_{L_{p}(0, \infty)}=p^{\prime}\|f\|_{\operatorname{Cop}(p)},
\end{aligned}
$$

and, applying 2.1 once more, we conclude that $\|f\|_{1-1 / p, p} \approx\|f\|_{\operatorname{Cop}(p)}$.

(iii) For $I=[0,1]$ and $f \in L_{1}+L_{1}(1 / s)=L_{1}$ we have $K\left(t, f ; L_{1}, L_{1}(1 / s)\right)$ $=\|f\|_{1}$ if $t \geq 1$, and

$$
K\left(t, f ; L_{1}, L_{1}(1 / s)\right)=\int_{0}^{t}|f(s)| d s+t \int_{t}^{1} \frac{|f(s)|}{s} d s=t C f(t)+t C^{*} f(t)
$$

if $0<t \leq 1$. Therefore, for $1<p<\infty$,

$$
\begin{aligned}
\|f\|_{1-1 / p, p} & =\left(\int_{0}^{1}\left[C f(t)+C^{*} f(t)\right]^{p} d t+\int_{1}^{\infty} t^{-p}\|f\|_{1}^{p} d t\right)^{1 / p} \\
& =\left(\left\|C f+C^{*} f\right\|_{p}^{p}+\frac{1}{p-1}\|f\|_{1}^{p}\right)^{1 / p} .
\end{aligned}
$$

Firstly, the last expression is not smaller than $\left\|C^{*} f\right\|_{p}=\|f\|_{\operatorname{Cop}(p)}$. On the other hand, since again $C C^{*} f(t)=C f(t)+C^{*} f(t)$, by the Hardy inequality, it follows that

$$
\begin{aligned}
\|f\|_{1-1 / p, p} & =\left(\left\|C C^{*} f\right\|_{p}^{p}+\frac{1}{p-1}\|f\|_{1}^{p}\right)^{1 / p} \leq\left\|C C^{*} f\right\|_{p}+(p-1)^{-1 / p}\|f\|_{1} \\
& \leq p^{\prime}\left\|C^{*} f\right\|_{p}+(p-1)^{-1 / p}\|f\|_{\operatorname{Cop}(p)}=\left(p^{\prime}+(p-1)^{-1 / p}\right)\|f\|_{\operatorname{Cop}(p)} .
\end{aligned}
$$

Thus, $\left(L_{1}, L_{1}(1 / t)\right)_{1-1 / p, p}=\operatorname{Cop}_{p}$ with equivalent norms for $1<p<\infty$. For $p=\infty$ we have $\left(L_{1}, L_{1}(1 / t)\right)_{1, \infty}=L_{1}(1 / t)=\operatorname{Cop}_{\infty}[0,1]$.

The imbedding $\operatorname{Cop}_{p} \stackrel{p^{\prime}}{\rightarrow} \operatorname{Ces}_{p}$ for $1<p \leq \infty$ follows from the inequality $\|f\|_{\operatorname{Ces}(p)}=\|C f\|_{p} \leq\left\|C f+C^{*} f\right\|_{p}=\left\|C C^{*} f\right\|_{p} \leq p^{\prime}\left\|C^{*} f\right\|_{p}=p^{\prime}\|f\|_{\operatorname{Cop}(p)}$.

Moreover, $\operatorname{Ces}_{p}[0,1] \cap L_{1}[0,1] \stackrel{p+1}{\hookrightarrow} \operatorname{Cop}_{p}[0,1]$ for $1 \leq p<\infty$. In fact, observe that in the case of $I=[0,1]$ the composition operator $C^{*} C$ has an additional 
term. More precisely,

$$
C^{*} C f(t)=C f(t)+C^{*} f(t)-\int_{0}^{1}|f(s)| d s .
$$

Therefore,

$$
\begin{aligned}
\|f\|_{\text {Cop }(p)} & =\left\|C^{*} f\right\|_{p} \leq\left\|C f+C^{*} f\right\|_{p} \\
& =\left\|C^{*} C f+\int_{0}^{1}|f(s)| d s\right\|_{p} \leq\left\|C^{*} C f\right\|_{p}+\|f\|_{1} \\
& \leq p\|C f\|_{p}+\|f\|_{1} \leq(p+1) \max \left(\|f\|_{\operatorname{Ces}(p)},\|f\|_{1}\right) .
\end{aligned}
$$

Finally, let us show that $\mathrm{Ces}_{p} \leadsto \mathrm{Cop}_{p}$ by comparing norms of the functions $f_{h}(t)=\frac{1}{\sqrt{1-t}} \chi_{[h, 1)}(t), 0<h<1$, in these spaces. We have

$$
C^{*}\left(f_{h}\right)(t)= \begin{cases}\int_{h}^{1} \frac{1}{s \sqrt{1-s}} d s & \text { if } 0<t \leq h, \\ \int_{t}^{1} \frac{1}{s \sqrt{1-s}} d s & \text { if } h \leq t \leq 1,\end{cases}
$$

and

$$
\begin{aligned}
\left\|f_{h}\right\|_{\mathrm{Cop}(p)}^{p} & =\left\|C^{*}\left(f_{h}\right)\right\|_{p}^{p} \geq \int_{0}^{h}\left(\int_{h}^{1} \frac{1}{s \sqrt{1-s}} d s\right)^{p} d t=h\left(\int_{h}^{1} \frac{1}{s \sqrt{1-s}} d s\right)^{p} \\
& \geq h\left(\int_{h}^{1} \frac{1}{\sqrt{1-s}} d s\right)^{p}=2^{p} h(1-h)^{p / 2} .
\end{aligned}
$$

Also,

$$
C\left(f_{h}\right)(t)= \begin{cases}0 & \text { if } 0<t \leq h \\ (2 / t)(\sqrt{1-h}-\sqrt{1-t}) & \text { if } h \leq t \leq 1\end{cases}
$$

and

$$
\begin{aligned}
\left\|f_{h}\right\|_{\operatorname{Ces}(p)}^{p} & =\left\|C\left(f_{h}\right)\right\|_{p}^{p}=2^{p} \int_{h}^{1}\left(\frac{\sqrt{1-h}-\sqrt{1-t}}{t}\right)^{p} d t \\
& \leq 2^{p} \int_{h}^{1} \frac{(1-h)^{p / 2}}{t^{p}} d t=2^{p}(1-h)^{p / 2} \frac{1-h^{p-1}}{(p-1) h^{p-1}} .
\end{aligned}
$$

Thus,

$\frac{\left\|f_{h}\right\|_{\operatorname{Cop}(p)}^{p}}{\left\|f_{h}\right\|_{\operatorname{Ces}(p)}^{p}} \geq \frac{2^{p} h(1-h)^{p / 2}(p-1) h^{p-1}}{2^{p}(1-h)^{p / 2}\left(1-h^{p-1}\right)}=(p-1) \frac{h^{p}}{1-h^{p-1}} \rightarrow \infty$ as $h \rightarrow 1^{+}$,

and the proof is complete. 
Remark 2.2. Alternatively, the space $\operatorname{ces}_{p}$ for $1<p<\infty$ can be obtained as an interpolation space with respect to $\left(l_{1}, l_{1}\left(2^{-n}\right)\right)$ by the socalled $K^{+}$-method, a version of the standard $K$-method, precisely, $\operatorname{ces}_{p}=$ $\left(l_{1}, l_{1}\left(2^{-n}\right)\right)_{l_{p}(1 / n)}^{K^{+}}($cf. [CFM, proof of Theorem 6.4]).

REMARK 2.3. The results in Theorem 2.1 give a description of the real interpolation spaces $\left(L_{1}, L_{1}(1 / t)\right)_{1-1 / p, p}$ in the off-diagonal case. Before it was only known that they are intersections of weighted $L_{1}(w)$-spaces with the weights $w$ from certain sets (cf. [Gi, Theorem 4.1], [MP, Theorem 2]) or some block spaces (cf. [AKMNP, Lemma 3.1]).

The following corollary follows directly from Theorem 2.1, the reiteration formula $(1.2)$ and the equalities $\operatorname{Cop}_{\infty}[0,1]=L_{1}(1 / t)$ and $\operatorname{Cop}_{1}[0,1]=L_{1}$.

Corollary 2.4. If $1<p_{0}<p_{1}<\infty$ and $1 / p=(1-\theta) / p_{0}+\theta / p_{1}$ with $0<\theta<1$, then

$$
\left(\operatorname{ces}_{p_{0}}, \operatorname{ces}_{p_{1}}\right)_{\theta, p}=\operatorname{ces}_{p}, \quad\left(\operatorname{Ces}_{p_{0}}[0, \infty), \operatorname{Ces}_{p_{1}}[0, \infty)\right)_{\theta, p}=\operatorname{Ces}_{p}[0, \infty) .
$$

If $1 \leq p_{0}<p_{1} \leq \infty$ and $1 / p=(1-\theta) / p_{0}+\theta / p_{1}$ with $0<\theta<1$, then

$$
\left(\operatorname{Cop}_{p_{0}}[0,1], \operatorname{Cop}_{p_{1}}[0,1]\right)_{\theta, p}=\operatorname{Cop}_{p}[0,1] \text {. }
$$

REMARK 2.5. A different proof of the second equality in 2.2 was given by Sinnamon [Si91, Corollary 2].

3. Cesàro spaces on $[0, \infty)$ as interpolation spaces with respect to $\left(L_{1}, \mathrm{Ces}_{\infty}\right)$. All the spaces considered in this part are on the interval $I=[0, \infty)$. By [MS, p. 194] we have $D^{\infty}:=\left(L_{\infty}\right)^{\downarrow}=\mathrm{Ces}_{\infty}$ isometrically. On the other hand, for a Banach lattice $F$ with the Fatou property we have $F \in$ $\operatorname{Int}\left(L_{1}, D^{\infty}\right)=\operatorname{Int}\left(L_{1}, \operatorname{Ces}_{\infty}\right)$ if and only if $F=E^{\downarrow}$ with equality of norms for some $E \in \operatorname{Int}\left(L_{1}, L_{\infty}\right)$ (see [MS, Theorem 6.4]). Then, in particular, $L_{p}^{\downarrow} \in \operatorname{Int}\left(L_{1}, \operatorname{Ces}_{\infty}\right)$. Since the operator $C$ is bounded in $L_{p}$ for $1<p \leq \infty$, by [Si01, Theorem 3.1] it follows that

$$
\|f\|_{L_{p}^{\downarrow}}=\||f|\|_{L_{p}^{\downarrow}} \approx\|C f\|_{L_{p}}=\|f\|_{\operatorname{Ces}(p)} .
$$

Thus, for any $1<p<\infty$ we have $\operatorname{Ces}_{p} \in \operatorname{Int}\left(L_{1}, \operatorname{Ces}_{\infty}\right)$ and $\operatorname{Ces}_{p}=L_{p}^{\downarrow}$.

Moreover, by using Theorem 6.4 from [MS], it is easy to prove the following more precise and general assertion.

Proposition 3.1. Let $E, F \in \operatorname{Int}\left(L_{1}, L_{\infty}\right)$ and $\Phi$ be an interpolation Banach lattice with respect to the couple $\left(L_{\infty}, L_{\infty}(1 / u)\right)$ on $(0, \infty)$. Then

$$
\left(E^{\downarrow}, F^{\downarrow}\right)_{\Phi}^{K}=\left[(E, F)_{\Phi}^{K}\right]^{\downarrow} .
$$

In particular, if $1<p<\infty$, then

$$
\left(L_{1}, \mathrm{Ces}_{\infty}\right)_{1-1 / p, p}=\mathrm{Ces}_{p} .
$$


Proof. Firstly, since the Banach couple $\left(L_{1}, L_{\infty}\right)$ is $K$-monotone [KPS, Theorem 2.4.3], by the assumption and the Brudnyı̌-Krugljak theorem (cf. [BK, Theorem 4.4.5]), $E=\left(L_{1}, L_{\infty}\right)_{\Phi_{0}}^{K}$ and $F=\left(L_{1}, L_{\infty}\right)_{\Phi_{1}}^{K}$ with some interpolation Banach lattices $\Phi_{0}$ and $\Phi_{1}$ with respect to the couple $\left(L_{\infty}, L_{\infty}(1 / u)\right)$ on $(0, \infty)$. Applying the reiteration theorem for the general $K$-method (see [BK, Theorem 3.3.11]), we obtain

$$
(E, F)_{\Phi}^{K}=\left(\left(L_{1}, L_{\infty}\right)_{\Phi_{0}}^{K},\left(L_{1}, L_{\infty}\right)_{\Phi_{1}}^{K}\right)_{\Phi}^{K}=\left(L_{1}, L_{\infty}\right)_{\Psi}^{K},
$$

where $\Psi=\left(\Phi_{0}, \Phi_{1}\right)_{\Phi}^{K}$. Moreover, from the proof of Theorem 6.4 in [MS] and the equality $L_{1}^{\downarrow}=L_{1}$ (see Section 1 ) it follows that

$$
E^{\downarrow}=\left[\left(L_{1}, L_{\infty}\right)_{\Phi_{0}}^{K}\right]^{\downarrow}=\left(L_{1}, D^{\infty}\right)_{\Phi_{0}}^{K}, F^{\downarrow}=\left[\left(L_{1}, L_{\infty}\right)_{\Phi_{1}}^{K}\right]^{\downarrow}=\left(L_{1}, D^{\infty}\right)_{\Phi_{1}}^{K}
$$

and

$$
\left[(E, F)_{\Phi}^{K}\right]^{\downarrow}=\left[\left(L_{1}, L_{\infty}\right)_{\Psi}^{K}\right]^{\downarrow}=\left(L_{1}, D^{\infty}\right)_{\Psi}^{K} .
$$

Therefore, using the reiteration theorem once again, we obtain

$$
\left(E^{\downarrow}, F^{\downarrow}\right)_{\Phi}^{K}=\left(\left(L_{1}, D^{\infty}\right)_{\Phi_{0}}^{K},\left(L_{1}, D^{\infty}\right)_{\Phi_{1}}^{K}\right)_{\Phi}^{K}=\left(L_{1}, D^{\infty}\right)_{\Psi}^{K}=\left[(E, F)_{\Phi}^{K}\right]^{\downarrow} .
$$

and equality (3.1) is proved. In particular, from (3.1) and the well-known identification formula $\left(L_{1}, L_{\infty}\right)_{1-1 / p, p}=L_{p}$ [BL, Theorem 5.2.1] it follows that

$$
\left(L_{1}, \operatorname{Ces}_{\infty}\right)_{1-1 / p, p}=\left(L_{1}^{\downarrow}, L_{\infty}^{\downarrow}\right)_{1-1 / p, p}=L_{p}^{\downarrow}=\operatorname{Ces}_{p},
$$

and equality 3.2 is also proved.

For a given symmetric space $E$ on $I=[0, \infty)$ the Cesàro function space $\operatorname{Ces}_{E}$ is defined by the norm $\|f\|_{\operatorname{Ces}(E)}=\|C f\|_{E}$. If the operator $C$ is bounded in $E$, then, by [Si01, Theorem 3.1], $\operatorname{Ces}_{E}=E^{\downarrow}$. Therefore, applying Proposition 3.1, we obtain

Corollary 3.2. Let the operator $C$ be bounded in symmetric spaces $E$ and $F$ on $[0, \infty)$ and let $\Phi$ be an interpolation Banach lattice with respect to the couple $\left(L_{\infty}, L_{\infty}(1 / u)\right)$ on $(0, \infty)$. Then

$$
\left(\operatorname{Ces}_{E}, \operatorname{Ces}_{F}\right)_{\Phi}^{K}=\operatorname{Ces}_{(E, F)_{\Phi}^{K}} \text {. }
$$

In particular, for any $1<p_{0}<p_{1} \leq \infty$,

$$
\left(\operatorname{Ces}_{p_{0}}, \operatorname{Ces}_{p_{1}}\right)_{\theta, p}=\operatorname{Ces}_{p} \text {, where } 0<\theta<1 \text { and } \frac{1}{p}=\frac{1-\theta}{p_{0}}+\frac{\theta}{p_{1}} \text {. }
$$

REMARK 3.3. If $1<p<\infty$, then the restriction of the space $\operatorname{Ces}_{p}[0, \infty)$ to the interval $[0,1]$ coincides with $\operatorname{Ces}_{p}[0,1] \cap L_{1}[0,1]$ (cf. AM, Remark 5]). Therefore, if we "restrict" 3.3 to $[0,1]$ we obtain only

$$
\left(\operatorname{Ces}_{p_{0}}[0,1] \cap L_{1}[0,1], \operatorname{Ces}_{p_{1}}[0,1] \cap L_{1}[0,1]\right)_{\theta, p}=\operatorname{Ces}_{p}[0,1] \cap L_{1}[0,1],
$$

where $1<p_{0}<p_{1}<\infty$ and $1 / p=(1-\theta) / p_{0}+\theta / p_{1}$. 
4. Cesàro spaces on $[0,1]$ as interpolation spaces with respect to $\left(L_{1}(1-t), \operatorname{Ces}_{\infty}\right)$. In contrast to the case of $[0, \infty), \operatorname{Ces}_{p}[0,1]$ for $1 \leq p<\infty$ is not even an intermediate space between $L_{1}[0,1]$ and $\operatorname{Ces}_{\infty}[0,1]$. In fact, $\operatorname{Ces}_{\infty}[0,1] \hookrightarrow L_{1}[0,1]$, but it is easy to show that $\operatorname{Ces}_{p}[0,1] \not \subset L_{1}[0,1]$ for every $1 \leq p<\infty$.

On the other hand, from the inequality $1-u \leq \ln (1 / u)(0<u \leq 1)$ it follows that $\operatorname{Ces}_{p}[0,1], 1 \leq p<\infty$, is an intermediate space between $L_{1}(1-t)[0,1]$ and $\operatorname{Ces}_{\infty}[0,1]$, because

$$
\operatorname{Ces}_{\infty}[0,1] \stackrel{1}{\hookrightarrow} \operatorname{Ces}_{p}[0,1] \stackrel{1}{\hookrightarrow} \operatorname{Ces}_{1}[0,1]=L_{1}(\ln (1 / t))[0,1] \stackrel{1}{\hookrightarrow} L_{1}(1-t)[0,1] .
$$

TheOREM 4.1. If $1<p<\infty$, then

$$
\left(\operatorname{Ces}_{1}[0,1], \operatorname{Ces}_{\infty}[0,1]\right)_{1-1 / p, p} \stackrel{1}{\hookrightarrow} \operatorname{Ces}_{p}[0,1]
$$

and

$$
\left(L_{1}(1-t)[0,1], \operatorname{Ces}_{\infty}[0,1]\right)_{1-1 / p, p}=\operatorname{Ces}_{p}[0,1] .
$$

Proof. All function spaces in this proof are considered on $I=[0,1]$ unless indicated otherwise.

First, for any $f \in \mathrm{Ces}_{1}$ and all $0<t \leq 1$ we have

$$
K(t, f):=K\left(t, f ; \mathrm{Ces}_{1}, \operatorname{Ces}_{\infty}\right) \geq \int_{0}^{t}(C f)^{*}(s) d s .
$$

In fact, we can assume that $f \geq 0$. If $f=g+h, g \geq 0, h \geq 0, g \in \mathrm{Ces}_{1}$, $h \in \mathrm{Ces}_{\infty}$, then $C f=C g+C h$, and therefore, by (1.3),

$$
\begin{gathered}
\|g\|_{\operatorname{Ces}(1)}+t\|h\|_{\operatorname{Ces}(\infty)}=\|C g\|_{L_{1}}+t\|C h\|_{L_{\infty}} \\
\geq \inf \left\{\|y\|_{L_{1}}+t\|z\|_{L_{\infty}}: C f=y+z, y \in L_{1}, z \in L_{\infty}\right\} \\
=K\left(t, C f ; L_{1}, L_{\infty}\right)=\int_{0}^{t}(C f)^{*}(s) d s .
\end{gathered}
$$

Taking the infimum over all suitable $g$ and $h$ we get 4.3.

Next, by the definition of real interpolation spaces, we obtain

$$
\begin{aligned}
\|f\|_{1-1 / p, p}^{p} & \geq \int_{0}^{1}\left[t^{1 / p-1} K(t, f)\right]^{p} \frac{d t}{t}=\int_{0}^{1} t^{-p} K(t, f)^{p} d t \\
& \geq \int_{0}^{1} t^{-p}\left[\int_{0}^{t}(C f)^{*}(s) d s\right]^{p} d t \geq\|C f\|_{L_{p}[0,1]}^{p}=\|f\|_{\operatorname{Ces}(p)}^{p},
\end{aligned}
$$

and the proof of 4.1 is complete.

Before proceeding with the proof of $(4.2)$ we introduce the following notation: for a Banach function space $E$ on $I=[0, \infty)$ or $[0,1]$ and any set 
$A \subset I$, by $\left.E\right|_{A}$ we denote the subspace of $E$ which consists of all functions $f$ such that supp $f \subset A$. Let also $X_{p}:=\left(L_{1}(1-t), \operatorname{Ces}_{\infty}\right)_{1-1 / p, p}$. Since

$$
\|f\|_{X_{p}} \approx\left\|f \chi_{[0,1 / 2]}\right\|_{X_{p}}+\left\|f \chi_{[1 / 2,1]}\right\|_{X_{p}},
$$

to prove 4.2 it is sufficient to check that

$$
\begin{aligned}
& \left\|f \chi_{[0,1 / 2]}\right\|_{X_{p}} \approx\left\|f \chi_{[0,1 / 2]}\right\|_{\operatorname{Ces}(p)}, \\
& \left\|f \chi_{[1 / 2,1]}\right\|_{X_{p}} \approx\left\|f \chi_{[1 / 2,1]}\right\|_{\operatorname{Ces}(p)} .
\end{aligned}
$$

Firstly, since $\left.L_{1}(1-t)\right|_{[0,1 / 2]}=\left.L_{1}[0, \infty)\right|_{[0,1 / 2]}$ and

$$
\left.\operatorname{Ces}_{\infty}\right|_{[0,1 / 2]}=\left.\operatorname{Ces}_{\infty}[0, \infty)\right|_{[0,1 / 2]},
$$

by Proposition 3.1 (see (3.2)) we obtain

$$
\left\|f \chi_{[0,1 / 2]}\right\|_{X_{p}} \approx\left\|f \chi_{[0,1 / 2]}\right\|_{\left(L_{1}[0, \infty), \operatorname{Ces}_{\infty}[0, \infty)\right)_{1-1 / p, p}} \approx\left\|f \chi_{[0,1 / 2]}\right\|_{\operatorname{Ces}_{p}[0, \infty)} .
$$

Note that

$$
\left.\operatorname{Ces}_{p}[0, \infty)\right|_{[0,1 / 2]}=\left.\operatorname{Ces}_{p}[0,1]\right|_{[0,1 / 2]}
$$

with equivalence of norms. In fact, by [AM, Remark 5], $\left.\operatorname{Ces}_{p}[0, \infty)\right|_{[0,1]}=$ $\operatorname{Ces}_{p} \cap L_{1}$. If $\operatorname{supp} g \subset[0,1 / 2]$, then

$$
\|g\|_{L_{1}}=\int_{0}^{1 / 2}|g(s)| d s \leq 2^{1 / p}\left(\int_{1 / 2}^{1}\left(\frac{1}{t} \int_{0}^{t}|g(s)| d s\right)^{p} d t\right)^{1 / p} \leq 2^{1 / p}\|g\|_{\operatorname{Ces}(p)} .
$$

Combining this with the previous equality, we obtain (4.7). Clearly, 4.4 is an immediate consequence of (4.7) and 4.6).

Now, we prove 4.5). Since $\left(\left.L_{1}(1-s)\right|_{[1 / 2,1]},\left.\mathrm{Ces}_{\infty}\right|_{[1 / 2,1]}\right)$ is a complemented subcouple of $\left(L_{1}(1-s), \mathrm{Ces}_{\infty}\right)$, the well-known result of Baouendi and Goulaouic [BG, Theorem 1], valid for all interpolation methods (see also [Tr, Theorem 1.17.1]), yields

$$
\left\|f \chi_{[1 / 2,1]}\right\|_{X_{p}} \approx\left\|f \chi_{[1 / 2,1]}\right\|_{Y_{p}}
$$

where $Y_{p}:=\left(\left.L_{1}(1-s)\right|_{[1 / 2,1]},\left.\operatorname{Ces}_{\infty}\right|_{[1 / 2,1]}\right)_{1-1 / p, p}$. To prove 4.5$)$ it is sufficient to show that

$$
Y_{p}=\left.\operatorname{Ces}_{p}\right|_{[1 / 2,1]} .
$$

On the one hand, since $1-u \leq \ln (1 / u) \leq 2(1-u)$ for all $1 / 2 \leq u \leq 1$ and $\operatorname{Ces}_{1}=L_{1}(\ln (1 / s))$, we have $\left.\operatorname{Ces}_{1}\right|_{[1 / 2,1]}=\left.L_{1}(1-s)\right|_{[1 / 2,1]}$, and, by the imbedding 4.1), we obtain

$$
Y_{p}=\left.\left(\left.\operatorname{Ces}_{1}\right|_{[1 / 2,1]},\left.\operatorname{Ces}_{\infty}\right|_{[1 / 2,1]}\right)_{1-1 / p, p} \subset \operatorname{Ces}_{p}\right|_{[1 / 2,1]} .
$$

To prove the opposite imbedding we note, firstly, that for any function $h$ 
with $\operatorname{supp} h \subset[1 / 2,1]$ we have

$$
\|h\|_{\operatorname{Ces}(\infty)}=\sup _{1 / 2 \leq x \leq 1} \frac{1}{x} \int_{1 / 2}^{x}|h(s)| d s,
$$

whence

$$
\|h\|_{L_{1}}=\int_{1 / 2}^{1}|h(s)| d s \leq\|h\|_{\operatorname{Ces}(\infty)} \leq 2 \int_{1 / 2}^{1}|h(s)| d s=2\|h\|_{L_{1}} .
$$

Therefore, using the formula for the $K$-functional with respect to a couple of weighted $L_{1}$-spaces (see (1.4)), we obtain

$$
G(t, h) \leq K\left(t, h ;\left.L_{1}(1-s)\right|_{[1 / 2,1]},\left.\operatorname{Ces}_{\infty}\right|_{[1 / 2,1]}\right) \leq 2 G(t, h),
$$

where

$$
G(t, h)=K\left(t, h ;\left.L_{1}(1-s)\right|_{[1 / 2,1]},\left.L_{1}\right|_{[1 / 2,1]}\right)=\int_{1 / 2}^{1} \min (1-s, t)|h(s)| d s .
$$

Furthermore, let $\left.h \in L_{1}\right|_{[1 / 2,1]}$. Then

$$
C h(s)=\frac{1}{s} \int_{1 / 2}^{s}|h(u)| d u \geq \int_{1 / 2}^{s}|h(u)| d u
$$

whence

$$
(C h)^{*}(s) \geq \int_{1 / 2}^{1-s}|h(u)| d u, \quad 0<s \leq 1 .
$$

Therefore, for all $0 \leq t \leq 1$, we obtain

$$
\begin{aligned}
\int_{0}^{t}(C h)^{*}(s) d s & \geq \int_{0}^{t}\left(\int_{1 / 2}^{1-s}|h(u)| d u\right) d s \\
& =\int_{1 / 2}^{1-t}\left(\int_{0}^{t}|h(u)| d s\right) d u+\int_{1-t}^{1}\left(\int_{0}^{1-u}|h(u)| d s\right) d u \\
& =t \int_{1 / 2}^{1-t}|h(u)| d u+\int_{1-t}^{1}(1-u)|h(u)| d u=G(t, h) .
\end{aligned}
$$

From this inequality and the definition of $G(t, h)$ it follows that

$$
\int_{0}^{\min (1, t)}(C h)^{*}(s) d s \geq G(t, h)
$$

for all $t>0$. Hence, by 4.9 and the classical Hardy inequality, for every 
$h \in \operatorname{Ces}_{p}$ with $\operatorname{supp} h \subset[1 / 2,1]$ we have

$$
\begin{aligned}
\|h\|_{Y_{p}} & =\left(\int_{0}^{\infty} t^{-p} K\left(t, h ;\left.L_{1}(1-s)\right|_{[1 / 2,1]},\left.\operatorname{Ces}_{\infty}\right|_{[1 / 2,1]}\right)^{p} d t\right)^{1 / p} \\
& \leq 2\left(\int_{0}^{\infty} t^{-p} G(t, h)^{p} d t\right)^{1 / p} \\
& \leq 2\left(\int_{0}^{\infty} t^{-p}\left(\int_{0}^{\min (1, t)}(C h)^{*}(s) d s\right)^{p} d t\right)^{1 / p} \\
& \leq 2\left(\int_{0}^{1} t^{-p}\left(\int_{0}^{t}(C h)^{*}(s) d s\right)^{p} d t\right)^{1 / p}+2\left(\int_{1}^{\infty} t^{-p}\left(\int_{0}^{1}(C h)^{*}(s) d s\right)^{p} d t\right)^{1 / p} \\
& \leq 2\left[\frac{p}{p-1}\|C h\|_{L_{p}[0,1]}+\frac{1}{(p-1)^{1 / p}}\|C h\|_{L_{1}[0,1]}\right] \leq \frac{4 p}{p-1}\|h\|_{\operatorname{Ces}_{p}[0,1]} .
\end{aligned}
$$

Thus, $\left.\operatorname{Ces}_{p}\right|_{[1 / 2,1]} \subset Y_{p}, 4.8$ holds, and the proof is complete.

The following result is an immediate consequence of 4.2 and the reiteration equality 1.2 .

Corollary 4.2. If $1<p_{0}<p_{1} \leq \infty$ and $1 / p=(1-\theta) / p_{0}+\theta / p_{1}$ with $0<\theta<1$, then

$$
\left(\operatorname{Ces}_{p_{0}}[0,1], \operatorname{Ces}_{p_{1}}[0,1]\right)_{\theta, p}=\operatorname{Ces}_{p}[0,1] .
$$

REMARK 4.3. An inspection of the proof of Theorem 4.1 shows that

$$
\left(\left.\operatorname{Ces}_{1}\right|_{[1 / 2,1]},\left.\operatorname{Ces}_{\infty}\right|_{[1 / 2,1]}\right)_{1-1 / p, p}=\left.\operatorname{Ces}_{p}\right|_{[1 / 2,1]}
$$

for every $1<p<\infty$ with equivalence of norms.

Remark 4.4. Comparison of formulas from Remark 3.3 and Corollary 4.2 shows that the real method $(\cdot, \cdot)_{\theta, p}$ "well" interpolates the intersection of Cesàro spaces on $[0,1]$ with $L_{1}[0,1]$ or, more precisely,

$$
\begin{aligned}
\left(\operatorname{Ces}_{p_{0}}[0,1] \cap L_{1}[0,1], \operatorname{Ces}_{p_{1}}[0,1]\right. & \left.\cap L_{1}[0,1]\right)_{\theta, p} \\
& =\left(\operatorname{Ces}_{p_{0}}[0,1], \operatorname{Ces}_{p_{1}}[0,1]\right)_{\theta, p} \cap L_{1}[0,1]
\end{aligned}
$$

for all $1<p_{0}<p_{1} \leq \infty, 0<\theta<1$ and $1 / p=(1-\theta) / p_{0}+\theta / p_{1}$.

REMARK 4.5. We will see further that the imbedding (4.1) is strict for every $1<p<\infty$ and, even more, $\operatorname{Ces}_{p}[0,1]$ is not an interpolation space between $\operatorname{Ces}_{1}[0,1]$ and $\operatorname{Ces}_{\infty}[0,1]$. Thus, the weighted $L_{1}$-space $L_{1}(1-t)[0,1]$ is in a sense the "proper" end of the scale of Cesàro spaces $\operatorname{Ces}_{p}[0,1], 1<$ $p \leq \infty$. 
5. The $K$-functional for $\left(\operatorname{Ces}_{1}[0,1], \operatorname{Ces}_{\infty}[0,1]\right)$. In this section we will find an equivalent expression for the $K$-functional

$$
K(t, f)=K\left(t, f ; \operatorname{Ces}_{1}, \operatorname{Ces}_{\infty}\right)=K\left(t, f ; \operatorname{Ces}_{1}[0,1], \operatorname{Ces}_{\infty}[0,1]\right) .
$$

We start with a lemma giving its lower estimate. Let us introduce two functions defined on $(0,1]$ by

$$
\tau_{1}(t)=t / \ln (e / t) \quad \text { and } \quad \tau_{2}(t)=e^{-t} \quad \text { for } 0<t \leq 1 .
$$

It is easy to see that there exists a unique $t_{0} \in(0,1)$ such that $\tau_{1}\left(t_{0}\right)=\tau_{2}\left(t_{0}\right)$ and $\tau_{1}(t)<\tau_{2}(t)$ if and only if $0<t<t_{0}$.

Lemma 5.1 (lower estimates). Let $f \in \operatorname{Ces}_{1}[0,1], f \geq 0$ and $0<t \leq 1$.

(i) If $f_{0}=f \chi_{\left[0, \tau_{1}(t)\right] \cup\left[\tau_{2}(t), 1\right]}$, then

$$
K(t, f) \geq \frac{1}{4}\left\|f_{0}\right\|_{\operatorname{Ces}(1)} .
$$

(ii) If $f_{1}=f \chi_{\left[\tau_{1}(t), \tau_{2}(t)\right]}$, then

$$
K(t, f) \geq \frac{1}{e^{2}} t\left\|f_{1}\right\|_{\operatorname{Ces}(\infty)} .
$$

Proof. (i) Firstly, let us prove that

$$
K(t, f) \geq \frac{1}{3}\left\|f \chi_{\left[0, \tau_{1}(t)\right]}\right\|_{\operatorname{Ces}(1)} \quad \text { for all } 0<t \leq 1 .
$$

Let $f \in \mathrm{Ces}_{1}, f=g+h$, where $g \in \mathrm{Ces}_{1}, h \in \mathrm{Ces}_{\infty}$. We may assume that $f \geq 0$ and $0 \leq g \leq f, 0 \leq h \leq f$. Then

$$
\begin{aligned}
& 3\left(\|g\|_{\operatorname{Ces}(1)}+t\|h\|_{\operatorname{Ces}(\infty)}\right) \geq\|g\|_{\operatorname{Ces}(1)}+3 t\|h\|_{\operatorname{Ces}(\infty)} \\
& \quad \geq\left\|(f-h) \chi_{\left[0, \tau_{1}(t)\right]}\right\|_{\operatorname{Ces}(1)}+3 t\left\|h \chi_{\left[0, \tau_{1}(t)\right]}\right\|_{\operatorname{Ces}(\infty)} \\
& \quad=\left\|f \chi_{\left[0, \tau_{1}(t)\right]}\right\|_{\operatorname{Ces}(1)}-\left\|h \chi_{\left[0, \tau_{1}(t)\right]}\right\|_{\operatorname{Ces}(1)}+3 t\left\|h \chi_{\left[0, \tau_{1}(t)\right]}\right\|_{\operatorname{Ces}(\infty)} .
\end{aligned}
$$

Let us show that for any $v \in \operatorname{Ces}_{\infty}, v \geq 0$, with $\operatorname{supp} v \subset\left[0, \tau_{1}(t)\right]$ we have

$$
\|v\|_{\operatorname{Ces}(1)} \leq 3 t\|v\|_{\operatorname{Ces}(\infty)} .
$$

In fact, by the assumption on the support of $v$ and the Fubini theorem,

$$
\begin{aligned}
\|v\|_{\operatorname{Ces}(1)} & =\int_{0}^{\tau_{1}(t)}\left(\frac{1}{s} \int_{0}^{s} v(u) d u\right) d s+\int_{\tau_{1}(t)}^{1}\left(\frac{1}{s} \int_{0}^{\tau_{1}(t)} v(u) d u\right) d s \\
& =\int_{0}^{\tau_{1}(t)}\left(\frac{1}{s} \int_{0}^{s} v(u) d u\right) d s+\int_{0}^{1}\left(\int_{\tau_{1}(t)}^{1} \frac{1}{s} d s\right) v(u) d u \\
& =\int_{0}^{\tau_{1}(t)}\left(\frac{1}{s} \int_{0}^{s} v(u) d u\right) d s+\int_{0}^{\tau_{1}(t)} v(u) d u \ln \frac{1}{\tau_{1}(t)} .
\end{aligned}
$$


Since $\tau_{1}(t) \leq t$ it follows that

$$
\int_{0}^{\tau_{1}(t)}\left(\frac{1}{s} \int_{0}^{s} v(u) d u\right) d s \leq \tau_{1}(t) \sup _{0<s \leq \tau_{1}(t)} \frac{1}{s} \int_{0}^{s} v(u) d u \leq t\|v\|_{\operatorname{Ces}(\infty)} .
$$

Moreover,

$$
\begin{aligned}
\int_{0}^{\tau_{1}(t)} v(u) d u \ln \frac{1}{\tau_{1}(t)} & \leq \tau_{1}(t) \ln \frac{1}{\tau_{1}(t)} \sup _{0<s \leq \tau_{1}(t)} \frac{1}{s} \int_{0}^{s} v(u) d u \\
& =\frac{\ln \frac{1}{t}+\ln \ln \frac{e}{t}}{\ln \frac{e}{t}} t\|v\|_{\operatorname{Ces}(\infty)} \leq 2 t\|v\|_{\operatorname{Ces}(\infty)},
\end{aligned}
$$

and (5.6) follows. Combining this estimate for $v=h \chi_{\left[0, \tau_{1}(t)\right]}$ with (5.5) we conclude that

$$
3\left(\|g\|_{\operatorname{Ces}(1)}+t\|h\|_{\operatorname{Ces}(\infty)}\right) \geq\left\|f \chi_{\left[0, \tau_{1}(t)\right]}\right\|_{\operatorname{Ces}(1)} .
$$

Taking the infimum over all decompositions $f=g+h, g \in \mathrm{Ces}_{1}, h \in \mathrm{Ces}_{\infty}$ with $0 \leq g \leq f, 0 \leq h \leq f$ we obtain (5.4).

Next, since $\operatorname{Ces}_{1}=L_{1}(\ln (1 / s))$ and $\operatorname{Ces}_{\infty} \stackrel{1}{\hookrightarrow} L_{1}$, we have

$$
K\left(t, f ; L_{1}(\ln (1 / s)), L_{1}\right)=K\left(t, f ; \mathrm{Ces}_{1}, L_{1}\right) \leq K(t, f) .
$$

Therefore, applying the well-known equality

$$
K\left(t, f ; L_{1}(\ln (1 / s)), L_{1}\right)=\int_{0}^{1} \min (\ln (1 / s), t)|f(s)| d s
$$

and the elementary inequality

$$
\int_{0}^{1} \min (\ln (1 / s), t)|f(s)| d s \geq \int_{e^{-t}}^{1} \ln (1 / s)|f(s)| d s=\left\|f \chi_{\left[\tau_{2}(t), 1\right]}\right\|_{\operatorname{Ces}(1)},
$$

we obtain

$$
K(t, f) \geq\left\|f \chi_{\left[\tau_{2}(t), 1\right]}\right\|_{\operatorname{Ces}(1)} .
$$

Inequality (5.2) is an immediate consequence of the last inequality and (5.4). The proof of (i) is complete.

(ii) Since (5.3) is obvious for $t \in\left[t_{0}, 1\right]$, it can be assumed that $0<t<t_{0}$. Let again $f \in \mathrm{Ces}_{1}, f=g+h$, where $g \in \mathrm{Ces}_{1}, h \in \mathrm{Ces}_{\infty}$ and $0 \leq g \leq f$, $0 \leq h \leq f$. Then for any $c \in(0,1)$ we have

$$
\begin{aligned}
& \|g\|_{\operatorname{Ces}(1)}+t\|h\|_{\operatorname{Ces}(\infty)} \\
\geq & \left\|g \chi_{\left[\tau_{1}(t), \tau_{2}(t)\right]}\right\|_{\operatorname{Ces}(1)}+c t\left\|(f-g) \chi_{\left[\tau_{1}(t), \tau_{2}(t)\right]}\right\|_{\operatorname{Ces}(\infty)} \\
\geq & \left\|g \chi_{\left[\tau_{1}(t), \tau_{2}(t)\right]}\right\|_{\operatorname{Ces}(1)}-c t\left\|g \chi_{\left[\tau_{1}(t), \tau_{2}(t)\right]}\right\|_{\operatorname{Ces}(\infty)}+c t\left\|f \chi_{\left[\tau_{1}(t), \tau_{2}(t)\right]}\right\|_{\operatorname{Ces}(\infty)} .
\end{aligned}
$$


We want to show that for every positive function $w \in \mathrm{Ces}_{1}$ with $\operatorname{supp} w \subset$ $\left[\tau_{1}(t), \tau_{2}(t)\right]$

$$
\frac{1}{e^{2}} t\|w\|_{\operatorname{Ces}(\infty)} \leq\|w\|_{\operatorname{Ces}(1)} \quad \text { for any } 0<t<t_{0} .
$$

Since

$$
\begin{aligned}
\|w\|_{\operatorname{Ces}(1)} & =\int_{0}^{1} \frac{1}{s}\left[\int_{\tau_{1}(t)}^{s} w(u) d u \cdot \chi_{\left[\tau_{1}(t), \tau_{2}(t)\right]}(s)+\int_{\tau_{1}(t)}^{\tau_{2}(t)} w(u) d u \chi_{\left[\tau_{2}(t), 1\right]}(s)\right] d s \\
& =\int_{\tau_{1}(t)}^{\tau_{2}(t)}\left(\frac{1}{s} \int_{\tau_{1}(t)}^{s} w(u) d u\right) d s+\int_{\tau_{1}(t)}^{\tau_{2}(t)} w(u) d u \int_{\tau_{2}(t)}^{1} \frac{d s}{s} \\
& =\int_{\tau_{1}(t)}^{\tau_{2}(t)}\left(\int_{u}^{\tau_{2}(t)} \frac{d s}{s}\right) w(u) d u+\int_{\tau_{1}(t)}^{\tau_{2}(t)} w(u) d u \ln \frac{1}{\tau_{2}(t)} \\
& =\int_{\tau_{1}(t)}^{\tau_{2}(t)} w(u) \ln \frac{\tau_{2}(t)}{u} d u+t \int_{\tau_{1}(t)}^{\tau_{2}(t)} w(u) d u,
\end{aligned}
$$

to prove (5.8) it suffices to show that for all $t \in\left(0, t_{0}\right)$ and $s \in\left[\tau_{1}(t), \tau_{2}(t)\right]$ we have

$$
\frac{1}{e^{2}} t \int_{\tau_{1}(t)}^{s} w(u) d u \leq s\left[\int_{\tau_{1}(t)}^{\tau_{2}(t)} w(u) \ln \frac{\tau_{2}(t)}{u} d u+t \int_{\tau_{1}(t)}^{\tau_{2}(t)} w(u) d u\right]
$$

We consider the cases when $s \in\left[\tau_{1}(t), \tau_{2}(t) / e\right]$ and $s \in\left(\tau_{2}(t) / e, \tau_{2}(t)\right]$ separately. Define a unique $t_{1} \in\left(0, t_{0}\right)$ such that $\tau_{1}\left(t_{1}\right)=\tau_{2}\left(t_{1}\right) / e$ and note that the interval $\left[\tau_{1}(t), \tau_{2}(t) / e\right]$ is non-empty only if $0<t \leq t_{1}$. Let

$$
\varphi(s):=s \ln \frac{\tau_{2}(t)}{s} \quad \text { for } s \in\left[\tau_{1}(t), \tau_{2}(t) / e\right] .
$$

Since

$$
\varphi^{\prime}(s)=\ln \frac{\tau_{2}(t)}{s}-1=\ln \frac{\tau_{2}(t)}{e s} \geq 0 \quad \text { for all } s \in\left[\tau_{1}(t), \tau_{2}(t) / e\right],
$$

it follows that $\varphi$ increases. Therefore, $\varphi(s) \geq \varphi\left(\tau_{1}(t)\right)$ for all $s \in\left[\tau_{1}(t), \tau_{2}(t) / e\right]$ and so

$$
\begin{aligned}
s \int_{\tau_{1}(t)}^{\tau_{2}(t)} w(u) \ln \frac{\tau_{2}(t)}{u} d u & \geq s \ln \frac{\tau_{2}(t)}{s} \int_{\tau_{1}(t)}^{s} w(u) d u \\
& \geq \tau_{1}(t) \ln \frac{\tau_{2}(t)}{\tau_{1}(t)} \int_{\tau_{1}(t)}^{s} w(u) d u
\end{aligned}
$$


We show that

$$
\tau_{1}(t) \ln \frac{\tau_{2}(t)}{\tau_{1}(t)} \geq \frac{1}{e^{2}} t \quad \text { for all } 0<t \leq t_{1}
$$

The function

$$
\psi(t)=\frac{\tau_{1}(t)}{t} \ln \frac{\tau_{2}(t)}{\tau_{1}(t)}=\frac{\ln \frac{\ln \frac{e}{t}}{t}-t}{\ln \frac{e}{t}} \quad \text { for } t \in\left(0, t_{1}\right]
$$

is differentiable and its derivative is

$$
\psi^{\prime}(t)=-\left[(t+1)\left(1+\ln \frac{e}{t}\right)+\ln \tau_{1}(t)\right] /\left[t\left(\ln \frac{e}{t}\right)^{2}\right] .
$$

It is not hard to check that $\psi$ is increasing on $\left(0, t_{2}\right)$ and decreasing on $\left(t_{2}, t_{1}\right]$ with $t_{2} \in\left(0, t_{1}\right)$. Hence, by the definition of $t_{1}$, for all $t \in\left(0, t_{1}\right]$ we have

$$
\psi(t) \geq \min \left[\psi\left(0^{+}\right), \psi\left(t_{1}\right)\right]=\min \left(1, \ln ^{-1} \frac{e}{t_{1}}\right)=\ln ^{-1} \frac{e}{t_{1}}=t_{1}^{-1} e^{-1-t_{1}} \geq e^{-2} .
$$

Thus, we obtain (5.11). Combining it with (5.10), we obtain (5.9) in the case when $0<t \leq t_{1}$ and $s \in\left[\tau_{1}(t), \tau_{2}(t) / e\right]$.

In the second case, when $s \in\left(\tau_{2}(t) / e, \tau_{2}(t)\right]$, we have $s \geq e^{-1-t} \geq e^{-2}$ and so

$$
t \int_{\tau_{1}(t)}^{s} w(u) d u \leq e^{2} t s \int_{\tau_{1}(t)}^{\tau_{2}(t)} w(u) d u .
$$

Hence, 5.9 holds again, and so 5.8 is proved. Combining (5.8) and 5.7 with $c=e^{-2}$, we obtain

$$
\|g\|_{\operatorname{Ces}(1)}+t\|h\|_{\operatorname{Ces}(\infty)} \geq \frac{1}{e^{2}} t\left\|f_{1}\right\|_{\operatorname{Ces}(\infty)} \quad \text { for all } 0<t<t_{0} .
$$

Taking the infimum over all decompositions $f=g+h, g \in \mathrm{Ces}_{1}, h \in \mathrm{Ces}_{\infty}$ with $0 \leq g \leq f, 0 \leq h \leq f$ we come to (5.3), and the proof of (ii) is complete.

TheOREM 5.2. For every $f \in \operatorname{Ces}_{1}[0,1]$ we have

$$
\begin{array}{r}
\frac{1}{2 e^{2}}\left[\left\|f \chi_{\left[0, \tau_{1}(t)\right] \cup\left[\tau_{2}(t), 1\right]}\right\|_{\operatorname{Ces}(1)}+t\left\|f \chi_{\left[\tau_{1}(t), \tau_{2}(t)\right]}\right\|_{\operatorname{Ces}(\infty)}\right] \leq K\left(t, f ; \operatorname{Ces}_{1}, \operatorname{Ces}_{\infty}\right) \\
\leq\left\|f \chi_{\left[0, \tau_{1}(t)\right] \cup\left[\tau_{2}(t), 1\right]}\right\|_{\operatorname{Ces}(1)}+t\left\|f \chi_{\left[\tau_{1}(t), \tau_{2}(t)\right]}\right\|_{\operatorname{Ces}(\infty)}
\end{array}
$$

for all $0<t<1$, and $K\left(t, f ; \operatorname{Ces}_{1}, \operatorname{Ces}_{\infty}\right)=\|f\|_{\operatorname{Ces}(1)}$ for all $t \geq 1$.

Proof. The first inequality is a consequence of Lemma 5.1 and the definition of the $K$-functional. The equality $K\left(t, f ; \mathrm{Ces}_{1}, \mathrm{Ces}_{\infty}\right)=\|f\|_{\mathrm{Ces}(1)}$ $(t \geq 1)$ follows from the imbedding $\operatorname{Ces}_{\infty} \stackrel{1}{\hookrightarrow} \mathrm{Ces}_{1}$.

If a positive function $f \in \mathrm{Ces}_{1}[0,1]$ is decreasing, then the description of the $K$-functional can be simplified. 
TheOREM 5.3. If $f \in \operatorname{Ces}_{1}[0,1], f \geq 0$ and $f$ is decreasing, then

$$
\frac{1}{3}\left\|f \chi_{\left[0, \tau_{1}(t)\right]}\right\|_{\operatorname{Ces}(1)} \leq K\left(t, f ; \operatorname{Ces}_{1}, \operatorname{Ces}_{\infty}\right) \leq\left\|f \chi_{\left[0, \tau_{1}(t)\right]}\right\|_{\operatorname{Ces}(1)}
$$

for all $0<t<1$, and $K\left(t, f ; \mathrm{Ces}_{1}, \mathrm{Ces}_{\infty}\right)=\|f\|_{\mathrm{Ces}(1)}$ for all $t \geq 1$.

Proof. Taking into account the proof of Lemma 5.1(i) (see (5.4)) it suffices to prove the right-hand inequality in (5.12).

Let $f_{0}:=\left[f-f\left(\tau_{1}(t)\right)\right] \chi_{\left[0, \tau_{1}(t)\right]}$ and $f_{1}:=f-f_{0}$. Since $f \geq 0$ is decreasing, we have $\left\|f_{1}\right\|_{\operatorname{Ces}(\infty)}=f\left(\tau_{1}(t)\right)$. Therefore, by the Fubini theorem,

$$
\begin{aligned}
\left\|f_{0}\right\|_{\operatorname{Ces}(1)}+t\left\|f_{1}\right\|_{\operatorname{Ces}(\infty)} & \\
= & \int_{0}^{1} \frac{1}{s} \int_{0}^{s}\left[f(u)-f\left(\tau_{1}(t)\right)\right] \chi_{\left[0, \tau_{1}(t)\right]}(u) d u d s+t f\left(\tau_{1}(t)\right) \\
= & \int_{0}^{1} \frac{1}{s} \int_{0}^{s} f(u) \chi_{\left[0, \tau_{1}(t)\right]}(u) d u d s-f\left(\tau_{1}(t)\right) \int_{0}^{\tau_{1}(t)} \ln \frac{1}{u} d u+t f\left(\tau_{1}(t)\right) \\
= & \left\|f \chi_{\left[0, \tau_{1}(t)\right]}\right\|_{\operatorname{Ces}(1)}-f\left(\tau_{1}(t)\right) \tau_{1}(t)\left[1+\ln \frac{1}{\tau_{1}(t)}\right]+t f\left(\tau_{1}(t)\right) \\
= & \left\|f \chi_{\left[0, \tau_{1}(t)\right]}\right\|_{\operatorname{Ces}(1)}+t f\left(\tau_{1}(t)\right)\left[1-\frac{1+\ln \left(\ln \frac{e}{t} / t\right)}{\ln \frac{e}{t}}\right] \\
= & \left\|f \chi_{\left[0, \tau_{1}(t)\right]}\right\|_{\operatorname{Ces}(1)}-\frac{t f\left(\tau_{1}(t)\right) \ln \left(\ln \frac{e}{t}\right)}{\ln \frac{e}{t}} \leq\left\|f \chi_{\left[0, \tau_{1}(t)\right]}\right\|_{\operatorname{Ces}(1),}
\end{aligned}
$$

whence

$$
K\left(t, f ; \operatorname{Ces}_{1}, \operatorname{Ces}_{\infty}\right) \leq\left\|f \chi_{\left[0, \tau_{1}(t)\right]}\right\|_{\operatorname{Ces}(1)},
$$

and the desired result is proved.

6. Identification of the real interpolation spaces $\left(\mathrm{Ces}_{1}[0,1]\right.$, $\left.\operatorname{Ces}_{\infty}[0,1]\right)_{1-1 / p, p}$ for $1<p<\infty$. Let us define the weighted Cesàro function space $\operatorname{Ces}_{p}(\ln (e / t))[0,1]$ to consist of all Lebesgue measurable functions $f$ on $[0,1]$ such that

$$
\|f\|_{\operatorname{Ces}(p, \ln )}:=\left(\int_{0}^{1}\left(\frac{1}{x} \int_{0}^{x}|f(t)| d t\right)^{p} \ln \frac{e}{x} d x\right)^{1 / p}<\infty .
$$

Clearly, $\operatorname{Ces}_{p}(\ln (e / t))[0,1] \stackrel{1}{\hookrightarrow} \operatorname{Ces}_{p}[0,1]$ for every $1<p<\infty$, and this imbedding is strict.

Theorem 6.1. For $1<p<\infty$,

$$
\left(\operatorname{Ces}_{1}[0,1], \operatorname{Ces}_{\infty}[0,1]\right)_{1-1 / p, p}=\operatorname{Ces}_{p}\left(\ln \frac{e}{t}\right)[0,1] .
$$


Proof. Denote $X_{p}=\left(\mathrm{Ces}_{1}, \mathrm{Ces}_{\infty}\right)_{1-1 / p, p}, 1<p<\infty$. Using Theorem 5.2 on the $K$-functional for the couple $\left(\mathrm{Ces}_{1}, \operatorname{Ces}_{\infty}\right)$ on $[0,1]$, we have

$$
\begin{aligned}
\|f\|_{X_{p}} \leq & {\left[\int_{0}^{t_{0}} t^{-p}\left\|f \chi_{\left[0, \tau_{1}(t)\right]}\right\|_{\operatorname{Ces}(1)}^{p} d t\right]^{1 / p}+\left[\int_{0}^{t_{0}} t^{-p}\left\|f \chi_{\left[\tau_{2}(t), 1\right]}\right\|_{\operatorname{Ces}(1)}^{p} d t\right]^{1 / p} } \\
& +\left[\int_{0}^{t_{0}} t^{-p}\left(t\left\|f \chi_{\left[\tau_{1}(t), \tau_{2}(t)\right]}\right\|_{\operatorname{Ces}(\infty)}\right)^{p} d t\right]^{1 / p}+\left[\int_{t_{0}}^{\infty} t^{-p}\|f\|_{\operatorname{Ces}(1)}^{p} d t\right]^{1 / p} \\
= & I_{1}+I_{2}+I_{3}+I_{4},
\end{aligned}
$$

where

$$
\begin{aligned}
I_{1}= & {\left[\int_{0}^{t_{0}} t^{-p}\left(\int_{0}^{\tau_{1}(t)} C f(s) d s+\int_{\tau_{1}(t)}^{1} C\left(f \chi_{\left[0, \tau_{1}(t)\right]}\right)(s) d s\right)^{p} d t\right]^{1 / p} } \\
\leq & {\left[\int_{0}^{t_{0}} t^{-p}\left(\int_{0}^{\tau_{1}(t)} C f(s) d s\right)^{p} d t\right]^{1 / p} } \\
& +\left[\int_{0}^{t_{0}} t^{-p}\left(\int_{\tau_{1}(t)}^{1} C\left(f \chi_{\left[0, \tau_{1}(t)\right]}\right)(s) d s\right)^{p} d t\right]^{1 / p}=I_{11}+I_{12} .
\end{aligned}
$$

First of all, we estimate all five integrals from above. Since $\tau_{1}^{\prime}(t)=$ $(\ln (e / t)+1) /(\ln (e / t))^{2}$ and so $1 / \ln (e / t) \leq \tau_{1}^{\prime}(t) \leq 2 / \ln (e / t)$ for all $0<t \leq 1$, we get

$$
\begin{aligned}
I_{11}^{p} & \leq \int_{0}^{t_{0}} t^{-p}\left(\ln \frac{e}{t}\right)^{p-1}\left(\int_{0}^{\tau_{1}(t)} C f(s) d s\right)^{p} d t \\
& \leq \int_{0}^{t_{0}} \tau_{1}(t)^{-p}\left(\int_{0}^{\tau_{1}(t)} C f(s) d s\right)^{p} d \tau_{1}(t) .
\end{aligned}
$$

Putting $u=\tau_{1}(t)$ and using the classical Hardy inequality, we obtain

$$
\begin{aligned}
I_{11} & \leq\left[\int_{0}^{\tau_{1}\left(t_{0}\right)}\left(\frac{1}{u} \int_{0}^{u} C f(s) d s\right)^{p} d u\right]^{1 / p} \leq\left\|C^{2} f\right\|_{L_{p}[0,1]} \\
& \leq p^{\prime}\|C f\|_{L_{p}[0,1]}=p^{\prime}\|f\|_{\operatorname{Ces}(p)} \leq p^{\prime}\|f\|_{\operatorname{Ces}(p, \ln ) .}
\end{aligned}
$$

Next, by the estimate $\ln \left(1 / \tau_{1}(t)\right) \leq 2 \ln (e / t), 0<t \leq 1$, we get

$$
\begin{aligned}
I_{12}^{p} & =\int_{0}^{t_{0}} t^{-p}\left(\int_{\tau_{1}(t)}^{1}\left(\frac{1}{s} \int_{0}^{\tau_{1}(t)}|f(u)| d u\right) d s\right)^{p} d t \\
& =\int_{0}^{t_{0}} t^{-p}\left(\int_{0}^{\tau_{1}(t)}|f(u)| d u\right)^{p} \ln ^{p} \frac{1}{\tau_{1}(t)} d t \\
& \leq 2^{p} \int_{0}^{t_{0}} \tau_{1}(t)^{-p}\left(\int_{0}^{\tau_{1}(t)}|f(u)| d u\right)^{p} d t .
\end{aligned}
$$


The substitution $t=\tau_{1}^{-1}(s)$ and the inequalities

$$
\left(\tau_{1}^{-1}\right)^{\prime}(s)=\frac{1}{\tau_{1}^{\prime}\left(\tau_{1}^{-1}(s)\right)} \leq \ln \frac{e}{\tau_{1}^{-1}(s)} \leq \ln \frac{e}{s}
$$

show that

$$
\begin{aligned}
I_{12} & \leq 2\left[\int_{0}^{\tau_{1}\left(t_{0}\right)}\left(\frac{1}{s} \int_{0}^{s}|f(u)| d u\right)^{p} \ln \frac{e}{s} d s\right]^{1 / p} \\
& \leq 2\left[\int_{0}^{1}(C f(s))^{p} \ln \frac{e}{s} d s\right]^{1 / p}=2\|f\|_{\operatorname{Ces}(p, \ln )}
\end{aligned}
$$

From the equality $\operatorname{Ces}_{1}[0,1]=L_{1}(\ln (1 / u))$ and the inequalities $\ln (1 / u) \leq$ $e(1-u)(1 / e \leq u \leq 1)$ and $\tau_{2}(t)=e^{-t} \geq 1-t(0<t \leq 1)$ it follows that

$$
\begin{aligned}
I_{2}^{p} & =\int_{0}^{t_{0}} t^{-p}\left\|f \chi_{\left[\tau_{2}(t), 1\right]}\right\|_{\operatorname{Ces}(1)}^{p} d t=\int_{0}^{t_{0}} t^{-p}\left(\int_{\tau_{2}(t)}^{1}|f(u)| \ln \frac{1}{u} d u\right)^{p} d t \\
& \leq e^{p} \int_{0}^{t_{0}} t^{-p}\left(\int_{\tau_{2}(t)}^{1}|f(u)|(1-u) d u\right)^{p} d t \\
& \leq e^{p} \int_{0}^{t_{0}} t^{-p}\left(\int_{1-t}^{1}|f(u)|(1-u) d u\right)^{p} d t .
\end{aligned}
$$

Arguing in the same way as in the second part of the proof of Theorem 4.1. for $g=f \chi_{\left[e^{-1}, 1\right]}$ and $0<s \leq 1$ we have

$$
C g(s)=\frac{1}{s} \int_{e^{-1}}^{s}|f(u)| d u \geq \int_{e^{-1}}^{s}|f(u)| d u,
$$

whence $(C g)^{*}(s) \geq \int_{e^{-1}}^{1-s}|f(u)| d u$ and

$$
\begin{aligned}
\int_{0}^{t}(C g)^{*}(s) d s & \geq \int_{0}^{t}\left(\int_{e^{-1}}^{1-s}|f(u)| d u\right) d s \\
= & \int_{e^{-1}}^{1-t}\left(\int_{0}^{t}|f(u)| d s\right) d u+\int_{1-t}^{1}\left(\int_{0}^{1-u}|f(u)| d s\right) d u \geq \int_{1-t}^{1}|f(u)|(1-u) d u .
\end{aligned}
$$

Therefore, again by the Hardy inequality,

$$
\begin{aligned}
I_{2} & \leq e\left[\int_{0}^{t_{0}} t^{-p}\left(\int_{0}^{t}(C g)^{*}(s) d s\right)^{p} d t\right]^{1 / p} \leq e\left\|C\left[(C g)^{*}\right]\right\|_{L_{p}[0,1]} \\
& \leq e p^{\prime}\left\|(C g)^{*}\right\|_{L_{p}[0,1]}=e p^{\prime}\|C g\|_{L_{p}[0,1]}=e p^{\prime}\left\|f \chi_{\left[e^{-1}, 1\right]}\right\|_{\operatorname{Ces}(p)} \\
& \leq e p^{\prime}\|f\|_{\operatorname{Ces}(p)} \leq e p^{\prime}\|f\|_{\operatorname{Ces}(p, \ln ) .}
\end{aligned}
$$


For the third integral, we have

$$
\begin{aligned}
I_{3}= & {\left[\int_{0}^{t_{0}}\left\|f \chi_{\left[\tau_{1}(t), \tau_{2}(t)\right]}\right\|_{\operatorname{Ces}(\infty)}^{p} d t\right]^{1 / p} } \\
\leq & {\left[\int_{0}^{t_{0}} \sup _{\tau_{1}(t)<s \leq 1 / 2}\left(\frac{1}{s} \int_{0}^{s}\left|f(u) \chi_{\left[\tau_{1}(t), \tau_{2}(t)\right]}(u)\right| d u\right)^{p} d t\right]^{1 / p} } \\
& +\left[\int_{0}^{t_{0}} \sup _{1 / 2<s \leq \tau_{2}(t)}\left(\frac{1}{s} \int_{0}^{s}\left|f(u) \chi_{\left[\tau_{1}(t), \tau_{2}(t)\right]}(u)\right| d u\right)^{p} d t\right]^{1 / p} \\
= & {\left[\int_{0}^{t_{0}} \sup _{\tau_{1}(t)<s \leq 1 / 2}\left(\frac{1}{s} \int_{\tau_{1}(t)}^{s}|f(u)| d u\right)^{p} d t\right]^{1 / p} } \\
& +\left[\int_{0}^{t_{0}} \sup _{1 / 2<s \leq \tau_{2}(t)}\left(\frac{1}{s} \int_{\tau_{1}(t)}^{s}|f(u)| d u\right)^{p} d t\right]^{1 / p}=I_{31}+I_{32} .
\end{aligned}
$$

If $\tau_{1}(t)<s \leq 1 / 2$, then $2 s \leq 1$ and

$$
\begin{aligned}
\int_{\tau_{1}(t)}^{2 s}\left(\frac{1}{v} \int_{0}^{v}|f(u)| d u\right) d v \\
=\int_{0}^{\tau_{1}(t)}\left(\int_{\tau_{1}(t)}^{2 s} \frac{1}{v} d v\right)|f(u)| d u+\int_{\tau_{1}(t)}^{2 s}\left(\int_{u}^{2 s} \frac{1}{v} d v\right)|f(u)| d u \\
=\int_{0}^{\tau_{1}(t)}|f(u)| d u \ln \frac{2 s}{\tau_{1}(t)}+\int_{\tau_{1}(t)}^{2 s}|f(u)| \ln \frac{2 s}{u} d u \\
\geq \frac{2 s-\tau_{1}(t)}{2 s} \int_{\tau_{1}(t)}^{2 s}|f(u)| \ln \frac{2 s}{u} d u \geq \ln 2 \frac{2 s-\tau_{1}(t)}{2 s} \int_{\tau_{1}(t)}^{s}|f(u)| d u .
\end{aligned}
$$

Thus,

$$
\begin{aligned}
\sup _{\tau_{1}(t)<s \leq 1 / 2} \frac{1}{s} \int_{\tau_{1}(t)}^{s}|f(u)| d u & \leq \frac{2}{\ln 2} \sup _{\tau_{1}(t)<s \leq 1 / 2} \frac{1}{2 s-\tau_{1}(t)} \int_{\tau_{1}(t)}^{2 s} C f(v) d v \\
& \leq \frac{2}{\ln 2} \operatorname{MCf}\left(\tau_{1}(t)\right),
\end{aligned}
$$

where $M$ is the maximal Hardy-Littlewood operator on $[0,1]$. The above estimates show that

$$
I_{31} \leq \frac{2}{\ln 2}\left(\int_{0}^{t_{0}} M C f\left(\tau_{1}(t)\right)^{p} d t\right)^{1 / p} .
$$


Using once again the substitution $t=\tau_{1}^{-1}(s)$ and 6.2 , we obtain

$$
I_{31} \leq \frac{2}{\ln 2}\left[\int_{0}^{\tau_{1}\left(t_{0}\right)}[M C f(s)]^{p} \ln \frac{e}{s} d s\right]^{1 / p} \leq \frac{2}{\ln 2}\|M C f\|_{L_{p}(\ln (e / s))} .
$$

We will show in the next lemma that the maximal operator $M$ is bounded in $L_{p}(\ln (e / s))[0,1]$ for $1<p<\infty$, which implies that for some constant $B_{p} \geq 1$, which depends only on $p$, we have

$$
I_{31} \leq \frac{2 B_{p}}{\ln 2}\|C f\|_{L_{p}(\ln (e / s))}=\frac{2 B_{p}}{\ln 2}\|f\|_{\operatorname{Ces}(p, \ln )} .
$$

The second part of $I_{3}$ is estimated in the following way:

$$
\begin{aligned}
I_{32}^{p} & =\int_{0}^{t_{0}} \sup _{1 / 2<s \leq \tau_{2}(t)}\left(\frac{1}{s} \int_{\tau_{1}(t)}^{s}|f(u)| d u\right)^{p} d t \leq 2^{p} \int_{0}^{t_{0}}\left(\int_{\tau_{1}(t)}^{\tau_{2}(t)}|f(u)| d u\right)^{p} d t \\
& \leq 2^{p} \int_{0}^{t_{0}}\left(\frac{1}{\tau_{2}(t)} \int_{0}^{\tau_{2}(t)}|f(u)| d u\right)^{p} d t
\end{aligned}
$$

and, changing variable $s=\tau_{2}(t)=e^{-t}$, we obtain

$$
\begin{aligned}
I_{32} & \leq 2\left[\int_{e^{-t_{0}}}^{1}\left(\frac{1}{s} \int_{0}^{s}|f(u)| d u\right)^{p} \frac{d s}{s}\right]^{1 / p} \leq 2 e^{t_{0} / p}\left(\int_{0}^{1} C f(s)^{p} d s\right)^{1 / p} \\
& \leq 2 e\|f\|_{\operatorname{Ces}(p)} \leq 2 e\|f\|_{\operatorname{Ces}(p, \ln )} .
\end{aligned}
$$

Since $t_{0}>1 / 2$, for the last integral we have

$$
I_{4}=\frac{1}{(p-1)^{1 / p} t_{0}^{1-1 / p}}\|f\|_{\operatorname{Ces}(1)} \leq \frac{2}{p-1}\|f\|_{\operatorname{Ces}(1)} \leq \frac{2}{p-1}\|f\|_{\operatorname{Ces}(p, \ln )} .
$$

Finally, summing up the above estimates, we get $\|f\|_{X_{p}} \leq C_{p}\|f\|_{\operatorname{Ces}(p, \ln )}$, where $C_{p}$ depends only on $p$. Thus, the imbedding $\operatorname{Ces}(p, \ln ) \hookrightarrow X_{p}$ is proved.

Now, we proceed with estimations from below. Firstly, by (5.4),

$$
\|f\|_{X_{p}}^{p} \geq 3^{-p} \int_{0}^{t_{0}} t^{-p}\left\|f \chi_{\left[0, \tau_{1}(t)\right]}\right\|_{\operatorname{Ces}(1)}^{p} d t=3^{-p} I_{1}^{p} \geq 3^{-p} I_{12}^{p} .
$$

It is not hard to check that $\ln \frac{1}{\tau_{1}(t)}=\ln \frac{\ln (e / t)}{t} \geq e^{-1} \ln \frac{e}{t}$ for $t \in\left(0, t_{0}\right]$. Therefore,

$$
I_{12}^{p}=\int_{0}^{t_{0}} t^{-p}\left(\int_{0}^{\tau_{1}(t)}|f(u)| d u\right)^{p} \ln ^{p} \frac{1}{\tau_{1}(t)} d t \geq e^{-p} \int_{0}^{t_{0}} \tau_{1}(t)^{-p}\left(\int_{0}^{\tau_{1}(t)}|f(u)| d u\right)^{p} d t .
$$

Since $\tau_{1}^{\prime}(s) \leq 2 / \ln (e / s), \tau_{1}^{-1}(s) \leq s \ln (e / s)$ and $\ln \ln (e / s) \leq e^{-1} \ln (e / s)$ 
$(0<s \leq 1)$, we have

$$
\begin{aligned}
\left(\tau_{1}^{-1}\right)^{\prime}(s) & =\frac{1}{\tau_{1}^{\prime}\left(\tau_{1}^{-1}(s)\right)} \geq \frac{1}{2} \ln \frac{e}{\tau_{1}^{-1}(s)} \geq \frac{1}{2} \ln \frac{e}{s \ln (e / s)} \\
& =\frac{1}{2}\left(\ln \frac{e}{s}-\ln \ln \frac{e}{s}\right) \geq \frac{1}{2}\left(1-\frac{1}{e}\right) \ln \frac{e}{s} .
\end{aligned}
$$

Hence, after the substitution $t=\tau_{1}^{-1}(s)$, we obtain

$$
\begin{aligned}
I_{12}^{p} & \geq e^{-p} \frac{1}{2}\left(1-\frac{1}{e}\right) \int_{0}^{\tau_{1}\left(t_{0}\right)}\left(\frac{1}{s} \int_{0}^{s}|f(u)| d u\right)^{p} \ln \frac{e}{s} d s \\
& \geq \frac{1}{4} e^{-p} \int_{0}^{\tau_{1}\left(t_{0}\right)} C f(s)^{p} \ln \frac{e}{s} d s,
\end{aligned}
$$

and so, taking into account 6.3, we get

$$
\|f\|_{X_{p}}^{p} \geq 4^{-1}(3 e)^{-p} \int_{0}^{\tau_{1}\left(t_{0}\right)} C f(s)^{p} \ln \frac{e}{s} d s .
$$

On the other hand, by the definition of $t_{0}$,

$$
\begin{aligned}
\int_{\tau_{1}\left(t_{0}\right)}^{1} C f(s)^{p} \ln \frac{e}{s} d s & \leq \ln \frac{e}{\tau_{1}\left(t_{0}\right)} \int_{\tau_{1}\left(t_{0}\right)}^{1} C f(s)^{p} d s \leq\left(1+t_{0}\right)\|f\|_{\operatorname{Ces}(p)}^{p} \\
& \leq 2\|f\|_{\operatorname{Ces}(p)}^{p} \leq 2\|f\|_{X_{p}}^{p},
\end{aligned}
$$

where the last inequality follows from (4.1). Hence,

$$
\|f\|_{X_{p}} \geq 8^{-1 / p}(3 e)^{-1}\left(\int_{0}^{1} C f(s)^{p} \ln \frac{e}{s} d s\right)^{1 / p} \geq \frac{1}{72}\|f\|_{\operatorname{Ces}(p, \ln )},
$$

and the imbedding $X_{p} \hookrightarrow \operatorname{Ces}(p, \ln )$ is proved. Thus, the proof of Theorem 6.1 will be finished if we prove the lemma below.

Lemma 6.2. If $1<p<\infty$, then the maximal Hardy-Littlewood operator $M$ on $[0,1]$ is bounded in the weighted space $L_{p}(\ln (e / x))[0,1]=$ $L_{p}([0,1], \ln (e / x) d x)$.

Proof. Muckenhoupt [Mu, Theorem 2] proved that the maximal operator $M$ on $[0,1]$ is bounded in $L_{p}([0,1], w(x) d x)$ if and only if the weight $w(x)$ satisfies the so-called $A_{p}$-condition on $[0,1]$, that is,

$$
\sup _{(a, b) \subset[0,1]}\left(\frac{1}{b-a} \int_{a}^{b} w(x) d x\right)\left(\frac{1}{b-a} \int_{a}^{b} w(x)^{-1 /(p-1)} d x\right)^{p-1}<\infty .
$$

Therefore, it is enough to show that for all intervals $(a, b) \subset[0,1]$ we have

$$
\int_{a}^{b} \ln \frac{e}{x} d x\left(\int_{a}^{b}\left(\ln \frac{e}{x}\right)^{-1 /(p-1)} d x\right)^{p-1} \leq 2(b-a)^{p} .
$$


Note that for $t \in(0, b)$,

$$
\int_{t}^{b} \ln \frac{e}{x} d x=b \ln \frac{e}{b}-t \ln \frac{e}{t}+b-t
$$

and

$$
\begin{aligned}
\int_{t}^{b}\left(\ln \frac{e}{x}\right)^{-\alpha} d x & =b\left(\ln \frac{e}{b}\right)^{-\alpha}-t\left(\ln \frac{e}{t}\right)^{-\alpha}-\alpha \int_{t}^{b}\left(\ln \frac{e}{x}\right)^{-\alpha-1} d x \\
& \leq b\left(\ln \frac{e}{b}\right)^{-\alpha}-t\left(\ln \frac{e}{t}\right)^{-\alpha},
\end{aligned}
$$

where $\alpha>0$. Since the functions

$$
\varphi_{1}(t)=\frac{b \ln (e / b)-t \ln (e / t)+b-t}{b-t}
$$

and

$$
\varphi_{2}(t)=\frac{b(\ln (e / b))^{-\alpha}-t(\ln (e / t))^{-\alpha}}{b-t}
$$

are both decreasing on $(0, b)$ for every $0<b \leq 1$ it follows that $\max _{0<t<b} \varphi_{1}(t)$ $=\varphi_{1}\left(0^{+}\right)=\ln \left(e^{2} / b\right)$ and $\max _{0<t<b} \varphi_{2}(t)=\varphi_{2}\left(0^{+}\right)=\ln ^{-\alpha}(e / b)$. Therefore, setting $\alpha=1 /(p-1)$, for all $0 \leq a<b \leq 1$ we have

$$
\begin{aligned}
\frac{1}{(b-a)^{p}} \int_{a}^{b} \ln \frac{e}{x} d x\left[\int_{a}^{b}\left(\ln \frac{e}{x}\right)^{-1 /(p-1)} d x\right]^{p-1} & \leq \ln \frac{e^{2}}{b}\left[\left(\ln \left(\frac{e}{b}\right)\right)^{-1 /(p-1)}\right]^{p-1} \\
& =\frac{\ln \left(e^{2} / b\right)}{\ln (e / b)} \leq 2,
\end{aligned}
$$

and $(6.4)$ is proved.

7. $\operatorname{Ces}_{p}[0,1], 1<p<\infty$, is not an interpolation space between $\mathrm{Ces}_{1}[0,1]$ and $\operatorname{Ces}_{\infty}[0,1]$. We start with two lemmas (it is instructive to compare the first with 4.1) ).

LEMmA 7.1. If $1<p<\infty$, then

$$
\operatorname{Ces}_{p}[0,1] \hookrightarrow\left(\operatorname{Ces}_{1}[0,1], \operatorname{Ces}_{\infty}[0,1]\right)_{1-1 / p, \infty} .
$$

Proof. Let us consider the family of characteristic functions $f_{s}=\chi_{[0, s]}$, $0<s<1$. As we know (cf. Theorem 5.3),

$$
K\left(t, f_{s} ; \operatorname{Ces}_{1}, \operatorname{Ces}_{\infty}\right) \geq \frac{1}{3}\left\|f_{s} \chi_{\left[0, \tau_{1}(t)\right]}\right\|_{\operatorname{Ces}(1)} \quad \text { for all } t>0 .
$$

Since

$$
\begin{aligned}
\left\|f_{s} \chi_{\left[0, \tau_{1}(t)\right]}\right\|_{\operatorname{Ces}(1)} & =\left\|\chi_{\left[0, \min \left(s, \tau_{1}(t)\right)\right]}\right\|_{\operatorname{Ces}(1)}=\left\|\chi_{\left[0, \min \left(s, \tau_{1}(t)\right)\right]}\right\|_{L_{1}(\ln (1 / s))} \\
& =\int_{0}^{\min \left(s, \tau_{1}(t)\right)} \ln \frac{1}{s} d s=\min \left(s, \tau_{1}(t)\right)\left[\ln \frac{1}{\min \left(s, \tau_{1}(t)\right)}+1\right],
\end{aligned}
$$


it follows that for all $t$ such that $\tau_{1}(t) \leq s$ we have $\left\|f_{s} \chi_{\left[0, \tau_{1}(t)\right]}\right\|_{\operatorname{Ces}(1)} \geq$ $\tau_{1}(t) \ln \left(1 / \tau_{1}(t)\right)$. Therefore, using the inequality $\tau_{1}^{-1}(s) \leq s \ln (e / s)$ once again, for $0<s<e^{-1}$ we obtain

$$
\begin{aligned}
\left\|f_{s}\right\|_{\left(\operatorname{Ces}_{1}, \operatorname{Ces}_{\infty}\right)_{1-1 / p, \infty}} & =\sup _{t>0} t^{1 / p-1} K\left(t, f_{s} ; \operatorname{Ces}_{1}, \operatorname{Ces}_{\infty}\right) \\
& \geq \frac{1}{3} \sup _{t>0, \tau_{1}(t) \leq s} t^{1 / p-1} \tau_{1}(t) \ln \frac{1}{\tau_{1}(t)} \\
& \geq \frac{1}{3}\left(\tau_{1}^{-1}(s)\right)^{1 / p-1} s \ln \frac{1}{s} \geq \frac{1}{6}\left(s \ln \frac{e}{s}\right)^{1 / p-1} s \ln \frac{1}{s} \\
& \geq \frac{1}{6} s^{1 / p}\left(\ln \frac{e}{s}\right)^{1 / p} .
\end{aligned}
$$

On the other hand,

$$
\begin{aligned}
\left\|f_{s}\right\|_{\operatorname{Ces}_{p}} & =\left[\int_{0}^{s}\left(\frac{1}{u} \int_{0}^{u} \chi_{[0, s]}(v) d v\right)^{p} d u+\int_{s}^{1}\left(\frac{1}{u} \int_{0}^{u} \chi_{[0, s]}(v) d v\right)^{p} d u\right]^{1 / p} \\
& =\left(s+s^{p} \int_{s}^{1} u^{-p} d u\right)^{1 / p}=\left(s+\frac{s^{p}}{p-1}\left(s^{1-p}-1\right)\right)^{1 / p} \\
& =\left(\frac{p}{p-1} s-\frac{1}{p-1} s^{p}\right)^{1 / p} \leq\left(p^{\prime}\right)^{1 / p} s^{1 / p}
\end{aligned}
$$

Therefore, for $0<s<e^{-1}$,

whence

$$
\frac{\left\|f_{s}\right\|_{\left(\operatorname{Ces}_{1}, \operatorname{Ces}_{\infty}\right)_{1-1 / p, \infty}}}{\left\|f_{s}\right\|_{\operatorname{Ces}_{p}}} \geq \frac{\frac{1}{6} s^{1 / p}\left(\ln \frac{e}{s}\right)^{1 / p}}{\left(p^{\prime}\right)^{1 / p} s^{1 / p}} \geq \frac{1}{6 p^{\prime}}\left(\ln \frac{e}{s}\right)^{1 / p},
$$

$$
\sup _{0<s<1} \frac{\left\|f_{s}\right\|_{\left(\mathrm{Ces}_{1}, \mathrm{Ces}_{\infty}\right)_{1-1 / p, \infty}}}{\left\|f_{s}\right\|_{\operatorname{Ces}_{p}}}=\infty,
$$

which shows that 7.1 holds.

Recall that the characteristic function $\varphi(s, t)$ of an exact interpolation functor $\mathcal{F}$ is defined by the equality $\mathcal{F}(s \mathbb{R}, t \mathbb{R})=\varphi(s, t) \mathbb{R}$ for all $s, t>0$. By the Aronszajn-Gagliardo theorem (see [BL, Theorem 2.5.1] or [BK, Theorem 2.3.15]), for every Banach couple $\left(X_{0}, X_{1}\right)$ and every Banach space $X \in \operatorname{Int}\left(X_{0}, X_{1}\right)$ there is an exact interpolation functor $\mathcal{F}$ such that $\mathcal{F}\left(X_{0}, X_{1}\right)=X$.

Lemma 7.2. Let $1<p<\infty$. Suppose that $\operatorname{Ces}_{p}[0,1] \in \operatorname{Int}\left(\operatorname{Ces}_{1}[0,1]\right.$, $\left.\mathrm{Ces}_{\infty}[0,1]\right)$ and $\mathcal{F}$ is an exact interpolation functor such that

$$
\mathcal{F}\left(\operatorname{Ces}_{1}[0,1], \operatorname{Ces}_{\infty}[0,1]\right)=\operatorname{Ces}_{p}[0,1] .
$$

Then the characteristic function $\varphi(1, t)$ of $\mathcal{F}$ is equivalent to $t^{1 / p}$ for $0<t$ $\leq 1$. 
Proof. To simplify notation set $V_{p}:=\left.\operatorname{Ces}_{p}\right|_{[1 / 2,1]}(1 \leq p \leq \infty)$, that is, $V_{p}$ is the subspace of $\operatorname{Ces}_{p}[0,1]$ which consists of all functions $f$ such that $\operatorname{supp} f \subset[1 / 2,1]$. Since $\left(V_{1}, V_{\infty}\right)$ is a complemented subcouple of $\left(\operatorname{Ces}_{1}[0,1]\right.$, $\left.\operatorname{Ces}_{\infty}[0,1]\right)$, by $(7.2)$ and the equality in Remark 4.3 , we obtain

$$
\mathcal{F}\left(V_{1}, V_{\infty}\right)=V_{p}=\left(V_{1}, V_{\infty}\right)_{1-1 / p, p}
$$

Consider the sequence of functions $g_{k}(t)=\chi_{\left[1-2^{-k}, 1-2^{-k-1}\right]}(t), k=1,2, \ldots$, and the linear projection

$$
\operatorname{Pf}(t)=\sum_{k=1}^{\infty} 2^{k+1} \int_{1-2^{-k}}^{1-2^{-k-1}} f(s) d s \cdot g_{k}(t), \quad f \in V_{\infty} .
$$

We have

$$
\begin{aligned}
\|P f\|_{V_{\infty}} & \leq 2\|P f\|_{\left.L_{1}\right|_{[1 / 2,1]}} \leq 2 \sum_{k=1}^{\infty} 2^{k+1} \int_{1-2^{-k}}^{1-2^{-k-1}}|f(s)| d s \cdot 2^{-k-1} \\
& =2\|f\|_{\left.L_{1}\right|_{[1 / 2,1]}} \leq 2\|f\|_{V_{\infty}},
\end{aligned}
$$

and, since $1-u \leq \ln (1 / u) \leq 2(1-u)$ for $1 / 2 \leq u \leq 1$,

$$
\begin{aligned}
\|P f\|_{V_{1}} & \leq \sum_{k=1}^{\infty} 2^{k+1} \int_{1-2^{-k}}^{1-2^{-k-1}}|f(s)| d s \cdot \int_{1-2^{-k}}^{1-2^{-k-1}} \ln \frac{1}{t} d t \\
& \leq \sum_{k=1}^{\infty} 2^{k+2} \int_{1-2^{-k}}^{1-2^{-k-1}}|f(s)| d s \cdot \int_{1-2^{-k}}^{1-2^{-k-1}}(1-t) d t \\
& \leq \sum_{k=1}^{\infty} 2^{k+2} \cdot 2^{-2 k-1} \cdot \int_{1-2^{-k}}^{1-2^{-k-1}}|f(s)| d s \leq 4 \sum_{k=1}^{\infty} \int_{1-2^{-k}}^{1-2^{-k-1}}|f(s)|(1-s) d s \\
& \leq 4 \sum_{k=1}^{\infty} \int_{1-2^{-k}}^{1-2^{-k-1}}|f(s)| \ln \frac{1}{s} d s=4\|f\|_{L_{1}(\ln (1 / s))}=4\|f\|_{V_{1}} .
\end{aligned}
$$

Therefore, $P$ is a bounded linear projection from $V_{\infty}$ onto $\operatorname{Im} P_{\mid V_{\infty}}$ and from $V_{1}$ onto $\operatorname{Im} P_{\mid V_{1}}$. At the same time, it is easy to see that the sequence $\left\{2^{k+1} g_{k}\right\}_{k=1}^{\infty}$ is equivalent in $V_{\infty}$ (resp. in $V_{1}$ ) to the standard basis in $l_{1}$ (resp. in $\left.l_{1}\left(2^{-k}\right)\right)$. Hence, $\left(l_{1}, l_{1}\left(2^{-k}\right)\right)$ is a complemented subcouple of $\left(V_{1}, V_{\infty}\right)$ and therefore, by (6.3) and by the Baouendi-Goulaouic result [BG, Theorem 1] (see also [Tr, Theorem 1.17.1]),

$$
\mathcal{F}\left(l_{1}, l_{1}\left(2^{-k}\right)\right)=\left(l_{1}, l_{1}\left(2^{-k}\right)\right)_{1-1 / p, p} .
$$

In particular, from the last relation it follows that

$$
\mathcal{F}\left(\mathbb{R}, 2^{-k} \mathbb{R}\right)=\left(\mathbb{R}, 2^{-k} \mathbb{R}\right)_{1-1 / p, p}=2^{-k / p} \mathbb{R}
$$

uniformly in $k \in \mathbb{N}$. Since the characteristic function of any exact interpolation functor is quasi-concave [BK, Proposition 2.3.10], this implies the result. 
Theorem 7.3. For any $1<p<\infty$, $\operatorname{Ces}_{p}[0,1]$ is not an interpolation space between $\operatorname{Ces}_{1}[0,1]$ and $\operatorname{Ces}_{\infty}[0,1]$.

Proof. Assume that $\operatorname{Ces}_{p}[0,1]$ is an interpolation space between $\operatorname{Ces}_{1}[0,1]$ and $\operatorname{Ces}_{\infty}[0,1]$. Then there is an exact interpolation functor $\mathcal{F}$ such that 7.2 holds. By Lemma 7.2 the characteristic function $\varphi(1, t)$ of $\mathcal{F}$ is equivalent to $t^{1 / p}$ for $0<t \leq 1$. Therefore, for any Banach couple $\left(X_{0}, X_{1}\right)$ we have

$$
\mathcal{F}\left(X_{0}, X_{1}\right) \subset\left(X_{0}, X_{1}\right)_{\psi, \infty},
$$

where $\left(X_{0}, X_{1}\right)_{\psi, \infty}$ is the real interpolation space consisting of all $x \in X_{0}+X_{1}$ such that $\sup _{t>0} \frac{\psi(t)}{t} K\left(t, x ; X_{0}, X_{1}\right)<\infty$ and $\psi(t)=\min \left(1, t^{1 / p}\right)$ [BK, Proposition 3.8.6]. Since $\operatorname{Ces}_{\infty}[0,1] \stackrel{1}{\hookrightarrow} \operatorname{Ces}_{1}[0,1]$, applying $(7.4)$ to the couple $\left(\operatorname{Ces}_{1}[0,1], \operatorname{Ces}_{\infty}[0,1]\right)$ we obtain

$$
\mathcal{F}\left(\operatorname{Ces}_{1}[0,1], \operatorname{Ces}_{\infty}[0,1]\right) \subset\left(\operatorname{Ces}_{1}[0,1], \operatorname{Ces}_{\infty}[0,1]\right)_{1-1 / p, \infty},
$$

whence $\operatorname{Ces}_{p}[0,1] \subset\left(\operatorname{Ces}_{1}[0,1], \operatorname{Ces}_{\infty}[0,1]\right)_{1-1 / p, \infty}$. But in view of Lemma 7.1 the last imbedding does not hold, and the proof is complete.

Acknowledgements. Research of S. V. Astashkin was partially supported by RFBR (grant no. 12-01-00198-a).

\section{References}

[AKMNP] I. Asekritova, N. Krugljak, L. Maligranda, L. Nikolova and L.-E. Persson, Lions-Peetre reiteration formulas for triples and their applications, Studia Math. 145 (2001), 219-254.

[A] S. V. Astashkin, On the geometric properties of Cesàro spaces, Mat. Sb. 203 (2012), 61-80 (in Russian); English transl.: Sb. Math. 203 (2012), 514-533.

[AM] S. V. Astashkin and L. Maligranda, Structure of Cesàro function spaces, Indag. Math. (N.S.) 20 (2009), 329-379.

[BG] M. S. Baouendi et C. Goulaouic, Commutation de l'intersection et des foncteurs d'interpolation, C. R. Acad. Sci. Paris Sér. A-B 26 (1967), 313-315.

[Be] G. Bennett, Factorizing the classical inequalities, Mem. Amer. Math. Soc. 120 (1996), no. 576.

[BS] C. Bennett and R. Sharpley, Interpolation of Operators, Academic Press, New York, 1988.

[BL] J. Bergh and J. Löfström, Interpolation Spaces. An Introduction, Springer, Berlin, 1976.

[BK] Yu. A. Brudnyı̆ and N. Ya. Krugljak, Interpolation Functors and Interpolation Spaces, North-Holland, Amsterdam, 1991.

[CFM] F. Cobos, L. M. Fernández-Cabrera and M. Mastyło, Abstract limit J-spaces, J. London Math. Soc. (2) 82 (2010), 501-525.

[Gi] J. E. Gilbert, Interpolation between weighted $L^{p}$-spaces, Ark. Mat. 10 (1972), $235-249$.

[HLP] G. H. Hardy, J. E. Littlewood and G. Pólya, Inequalities, Cambridge Univ. Press, Cambridge, 1988. 
[KPS] S. G. Krein, Yu. I. Petunin, and E. M. Semenov, Interpolation of Linear Operators, Nauka, Moscow, 1978 (in Russian); English transl.: Amer. Math. Soc., Providence, 1982.

[KMP] A. Kufner, L. Maligranda and L.-E. Persson, The Hardy Inequality. About its History and Some Related Results, Vydavatelsky Servis, Plzen, 2007.

[MP] L. Maligranda and L.-E. Persson, Real interpolation between weighted $L^{p}$ and Lorentz spaces, Bull. Polish Acad. Sci. Math. 35 (1987), 765-778.

[MPS] L. Maligranda, N. Petrot and S. Suantai, On the James constant and Bconvexity of Cesàro and Cesàro-Orlicz sequences spaces, J. Math. Anal. Appl. 326 (2007), 312-331.

[MS] M. Mastyło and G. Sinnamon, A Calderón couple of down spaces, J. Funct. Anal. 240 (2006), 192-225.

[Mu B. Muckenhoupt, Weighted norm inequalities for the Hardy maximal function, Trans. Amer. Math. Soc. 165 (1972), 207-226.

[Ov] V. I. Ovchinnikov, The Method of Orbits in Interpolation Theory, Math. Rep. 1 (1984), no. 2, i-x and 349-515.

[Si91] G. Sinnamon, Interpolation of spaces defined by the level function, in: Harmonic Analysis (Sendai, 1990), ICM-90 Satell. Conf. Proc., Springer, Tokyo, 1991, 190-193.

[Si94] G. Sinnamon, Spaces defined by the level function and their duals, Studia Math. 111 (1994), 19-52.

[Si01] G. Sinnamon, The level function in rearrangement invariant spaces, Publ. Mat. 45 (2001), 175-198.

[Si07] G. Sinnamon, Monotonicity in Banach function spaces, in: NAFSA 8-Nonlinear Analysis, Function Spaces and Applications, Vol. 8, Czech. Acad. Sci., Praha, 2007, 204-240.

[Tr] H. Triebel, Interpolation Theory. Function Spaces. Differential Operators, Deutscher Verlag Wiss., Berlin, 1978.

Sergey V. Astashkin

Department of Mathematics and Mechanics

Samara State University

Acad. Pavlova 1

443011 Samara, Russia

E-mail: astashkin@samsu.ru
Lech Maligranda

Department of Engineering Sciences and Mathematics Luleå University of Technology SE-971 87 Luleå, Sweden E-mail: lech.maligranda@ltu.se

Received November 26, 2012

Revised version April 11, 2013 
